A Thousand Words: The Role of Authority in Tibetan Auto-cremation Rituals

\author{
Marah Leigh Litchford \\ Carolina Beach, North Carolina
}

Bachelor of Arts - Literature, University of North Carolina - Wilmington, 2008

Bachelor of Arts - Philosophy \& Religion, University of North Carolina - Wilmington, 2010

A Thesis presented to the Graduate Faculty of the University of Virginia in Candidacy for the Degree of Master of Arts

Department of Religion

University of Virginia

May, 2014 
Since 2009, a rash of self-immolations by both lay and monastic men and women has beset the Tibetan community. The most recent, as of this writing, was April 15, $2014 .{ }^{1}$ The total number of such deaths is widely disputed. Most accounts claim more than 130 since the protests began five years ago. ${ }^{2}$ These actions elicit visceral responses in onlookers. It would be easy to decry the horror; to deny that such drastic actions could be expressing anything other than desperation - one so absolute that it has driven the immolator to insanity. However, declaring the immolators merely insane or desperate is to deny their actions any meaning. Peeling away the layers to discover what is driving these actions inevitably means moving past the intentionally gut wrenching visuals to understand why an immolator would want others to witness their death in this fashion.

The first thing that must be accepted is that the act of self-immolation is not an unprecedented, aberrant act. Rather, it is a ritual behavior with a long and complicated history. Modern self-immolation may be a new facet of Tibetan culture, but the act is one that has brought conflict to the Buddhist community for centuries. ${ }^{3}$

The ritual itself, however destructive it may seem to witnesses, is actually a ritual of creation. From its inception, it was believed to create social and spiritual change. ${ }^{4}$ By the tenth century, it was believed that ritual immolators were capable of creating physical relics via the completion of their act. ${ }^{5}$ It appears contradictory to state that a ritual which centers on someone's death could be focused more towards creation than destruction. However, rituals of political self-immolation have all shared one common thread - the intentional creation of a final, devastating image for a crowd to witness.

The ritual in its Tibetan form appears to have been adapted from previous Chinese and Vietnamese methods, though this cannot be unequivocally proven. The aim of the modern ritual is two fold. Tibetan immolators seek to make manifest a powerful visual image, and resultant material copy of that image, thereby generating a relic of the ritual. The modern innovation on the practice is the second aim, to encourage the dissemination of that image to parties uninvolved in their conflict. The intention is that witnesses, and indeed government policies, will be moved to change by the power of the image.

\footnotetext{
1 Savetibet.org. International Campaign for Tibet, 16 Apr. 2014. Web. 29 Apr. 2014. <http:// www.savetibet.org/resources/fact-sheets/self-immolations-by-tibetans/>.

2 Savetibet.org. International Campaign for Tibet, 16 Apr. 2014. Web. 29 Apr. 2014. <http:// www.savetibet.org/resources/fact-sheets/self-immolations-by-tibetans/>.

${ }^{3}$ Benn, James A. "Burning For The Buddha." Editorial. N.p., n.d. Web. 29 Apr. 2014. <http:// robprideaux.com/dev blog/wp-content/uploads/2013/11/immolation1.pdf>.

${ }^{4}$ Benn, James A. Burning for the Buddha: Self-immolation in Chinese Buddhism. p.6 Honolulu: U of Hawai'i, 2007. Web. 29 Apr. 2014.

${ }^{5}$ Benn, James A. Burning for the Buddha: Self-immolation in Chinese Buddhism. p.34 Honolulu: $U$ of Hawai'i, 2007. Web. 29 Apr. 2014.
} 
In this way, self-immolation is a ritualized act of Buddhist warfare. It can be considered warfare because the act of ritualized religious self burning is modeled after military self burning as an act of self defense, which arose concurrently with the practice of religious self-burning. ${ }^{6}$ Further, self-immolations consistently happen in cycles. ${ }^{7}$ The deaths frequently happen in high volume before any political change is exacted. ${ }^{8}$ In this way, immolators were acting in tandem with one another, as an army would. Extending the military comparison, the produced relic image is the weapon, acting as a conduit through which to express the pain of the martyrdom to witnesses. ${ }^{9}$

In this paper, I seek to prove that modern Tibetan self-immolations are functioning as ritualized religious warfare - a warfare which is driven and shaped by extant authority figures. In this case, authority refers to authority derived scripturally, and by figures both secular and religious. It also refers to the self manifesting authority which the the self-immolators are generating as their numbers grow. The immolators see the act of self burning as a ritual of sacrifice performed to protect both their land and their religion. ${ }^{10}$ Tibetans have responded by canonizing the immolators, who are viewed as patriotic martyrs. ${ }^{11}$ As the number of immolations rises, each immolation is seen to be legitimized by previous immolations. ${ }^{12}$ As the canon grows and becomes more accepted, the immolators themselves are becoming an authority in their own right, outside the bounds of religious and secular officials. ${ }^{13}$ This authority which they have gained, is grounded in the implication that they are acting as protectors of both Tibet

\footnotetext{
6 Han, Christina. "Cremation and Body Burning in Five Dynasties China." Journal of Chinese Studies 55 (2012): n. pag. Web. 29 Apr. 2014. <http://www.cuhk.edu.hk/ics/journal/articles/v55p001.pdt>.

${ }^{7}$ Kelly, Brendan D. "Self-immolation, Suicide and Self-harm in Buddhist and Western Traditions." Transcultural Psychiatry 48 (2011): n. pag. Sage Publications. Web. 2 Dec. 2013. <http:// tps.sagepub.com.proxy.its.virginia.edu/content/48/3/299.full.pdf>.

8 Benn, James A. Burning for the Buddha: Self-immolation in Chinese Buddhism. p.81 Honolulu: $U$ of Hawai'i, 2007. Web. 29 Apr. 2014.

9 Murray Yang, Michelle. "Still Burning: Self-Immolation as Photographic Protest." (n.d.): n. pag. All Academic Research. Web. 1 Dec. 2013. <http://citation.allacademic.com//meta/ p_mla_apa_research_citation/1/9/1/2/7/pages191275/p191275-1.php>.

10 Blake, Matt. "A Serene Smile for Her Last Picture: Haunting Story of Nun, 17, Who Scrawled Final Message on Her Hand and Then Set Herself on Fire in Bid to Free Tibet." Mail Online. UK Daily Mail, 4 Dec. 2012. Web. 29 Apr. 2014. <http://www. dailymail.co.uk/news/article-2242808/Last-words-SangayDolma-Tibetan-nun-set-protest-We-warriors-snow-mountain.html>.

11 Thinley, Phurbu. "Dalai Lama Honours Martyrs on Tibet Anniversary." Phayul.com. N.p., 10 Mar. 2010. Web. 29 Apr. 2014. <http://www.phayul.com/news/article.aspx?id=26846>.

12 Benn, James A. Burning for the Buddha: Self-immolation in Chinese Buddhism. p.26 Honolulu: $U$ of Hawai'i, 2007. Web. 29 Apr. 2014.

${ }^{13}$ A Study of Tibetan Self-Immolations: February 27, 2009 - March 30, 2012 The History, The Motive, and The Reaction." Tibetan Women's Association, n.d. Web. 29 Apr. 2014. <http://tibetanwomen.org/wpcontent/uploads/2012/04/Self-Immolation-report.pdf>.
} 
and Tibet's secular and religious figureheads - and as such are acting with a higher authority than the wishes of said figureheads.

\section{A Brief History of Self-Immolation}

Modern study of the ritual of self-immolation relies heavily on the work of one man, the prolific immolation scholar and Buddhologist James A. Benn. Due to the graphic nature of the act of self-immolation, discussions on the subject tend to be somewhat sanitized and this has led to some confusion regarding proper linguistic references to the acts at hand. ${ }^{14}$ In order to better understand the ritual and its purposes, one must first actively clear away some of these cobwebs. What first must be dealt with is the question of terminology. Self-immolation has popularly come to mean what might more correctly be termed 'auto-cremation', a term in fact coined by Benn. Auto-cremation refers to the act of ritualized self-burning with the intent of suicide. The self immolations committed in recent years by Tibetans have all been auto-cremations. However, self immolation has at various points also referred to the cutting of skin, or the feeding of one's body to animals, as well as various other methods. Indeed, different self-immolation behaviors are still currently practiced, such as the burning of three fingers as an offering to the Buddha in China and Korea. ${ }^{15}$ For the purposes of clarity, all acts of self-immolation referred to from this point forward may be assumed to be auto-crematory unless otherwise stated. This scope of this article does not allow for the nuance necessary in explicating the full history of all self immolation behaviors. As the Tibetan self immolations have all been auto-crematory, all references to self immolation in this article will refer to acts of auto-crematory self immolation as it is understood in the popular modern sense.

\section{Scriptural Bases For Early Chinese Auto-Cremations}

Many elements leading to the eventual development of Tibetan self-immolation practices are unique. Of particular note is the fact the body burning was not a behavior endemic to the practice of early Buddhism, but rather was integrated into Buddhist practice following its introduction into China. Although there is record of the praise of self-sacrifice for the Buddha in Indian texts, this was not influential in building the eventual practice of auto-cremation as established by Chinese Buddhists.

"Rather than being a continuation or adaptation of an Indian practice, as far as we can tell, it was constructed on Chinese soil and drew on a range of ideas, such as a particular interpretation of an Indian text (the Saddharmapuÿøarîka, or

\footnotetext{
14 Benn, James A. "Burning For The Buddha." Editorial. N.p., n.d. Web. 29 Apr. 2014. <http:// robprideaux.com/dev_blog/wp-content/uploads/2013/11/immolation1.pdf>.

${ }^{15}$ Benn, James A. Burning for the Buddha: Self-immolation in Chinese Buddhism. p.13 Honolulu: $U$ of Hawai'i, 2007. Web. 29 Apr. 2014.
} 
Lotus Sûtra) and indigenous traditions, such as burning the body to bring rain, a practice that long predated the arrival of Buddhism in China."16

In order to justify the introduction of these 'apocryphal practices' into accepted Buddhist ritual, two statements were penned in the Fanwang jing and the Shouleng'yan jing to create 'a clear and unambiguous justification for burning the body' in Chinese Buddhist canon. ${ }^{17}$ Though the indigenous practice of auto-cremation was extant long before the writing of either of these texts, there is no clear information on how exactly they performed their self-burning rituals, or why it was felt necessary to preserve this type of ritual and incorporate it into Buddhist practice. According to Benn, what is known is only that the texts were penned in order to justify self burning as a moral activity with a historical precedent.

As such,

"The practice of auto- cremation was reinforced, vindicated, and embellished by the production of Chinese apocryphal sûtras, by the composition of biographies of auto-cremators, and by the inclusion of these texts in the Buddhist canon as exemplars of heroic practice."18

Again, it is unclear exactly why it was felt necessary to justify the introduction of self-burning rituals into Buddhist practice. However, there are some clues.

Chinese Buddhist scholarship was being imported from Indian texts. Indian literary tradition has a rich heritage of emphasis on metaphorical imagery and poetic language. Chinese scholarship did not reflect this same emphasis, focusing instead on more literal verbiage. For this reason, Benn warns us that there is no reason to believe that medieval Chinese scholars had any reason to interpret the imported Indian texts any way other than literally.

"The stories of these heroes are presented in a matter of fact manner as paradigms of true generosity. Medieval Chinese readers surely ought not to be blamed for the fact that the stories were originally composed in a literary environment that was clearly very different from that of their own classical heritage."19

\footnotetext{
${ }^{16}$ Benn, James A. Burning for the Buddha: Self-immolation in Chinese Buddhism. p.10 Honolulu: $U$ of Hawai'i, 2007. Web. 29 Apr. 2014.

17 Benn, James A. "Where Text Meets Flesh: Burning the Body as an Apocryphal Practice in Chinese Buddhism." University of Chicago, May 1998. Web. 29 Apr. 2014. <http://ccbs.ntu.edu.tw/FULLTEXT/JREPT/benn.htm>.
}

18 Benn, James A. Burning for the Buddha: Self-immolation in Chinese Buddhism. p.10 Honolulu: $U$ of Hawai'i, 2007. Web. 29 Apr. 2014.

19 Benn, James A. Burning for the Buddha: Self-immolation in Chinese Buddhism. p.13 Honolulu: $U$ of Hawai'i, 2007. Web. 29 Apr. 2014. 
Secondarily, during the period in which self burning arose as a religious practice, it was also becoming more widely accepted (and indeed, popular) across the country. ${ }^{20}$ In particular, Christina Han notes that military body burning was practiced at the "sight of impending demise" as a means to "protect one's honor."21 To explain by example, if a General were about to be captured, he might commit a suicide by burning. This achieved the end of disallowing his enemies from desecrating his body post-mortem, or dishonoring him by burying his body away from his home. Further, it allowed him to ensure that he could not be tortured into giving up the position of his compatriots. ${ }^{22}$ Similarly, Benn states that monks would not have been immune to these developments in Chinese society during imperial uprisings - as violence outside the monastery was 'endemic'. ${ }^{23}$ As such, even outside of the religious ritual, monks were known to immolate to avoid being taken by invading rebels. Monks who resisted in the fashion are remembered in biographies as holy immolators. ${ }^{24}$ So while there is no direct historical record that ritualized religious auto-cremation intentionally copied the military version, there is compelling evidence for this fact given that the practices arose concurrently. Perhaps more importantly, both were practiced when it was believed that one's self, or monastery, might be over run. In this way, the "purpose of suicidal burning... is that it helped maintain and even strengthen the relationships the enemy intended to disrupt." ${ }^{25}$ Further, auto-cremation in both the military and religious contexts served as a "means to preserve and not destroy the crucial bond between people, and between the person and the land."26 This point remains to be of particular significance in relation to modern Tibetan auto-cremation. It also demonstrates an important influence that may have led medieval Chinese scholars to work to legitimize the practice as morally acceptable - particularly in light of extant indigenous practices and the literal interpretation of Indian texts.

20Han, Christina. "Cremation and Body Burning in Five Dynasties China." Journal of Chinese Studies 55 (2012): n. pag. Web. 29 Apr. 2014. <http://www.cuhk.edu.hk/ics/journal/articles/v55p001.pdfs.

Yun-Hua, Jan. "Buddhist Self-Immolation in Medieval China." History of Religions 4.2 (1965): 243-68. JSTOR. Web. 29 Apr. 2014.

${ }^{21}$ Han, Christina. "Cremation and Body Burning in Five Dynasties China." p.11 Journal of Chinese Studies 55 (2012): n. pag. Web. 29 Apr. 2014. <http://www.cuhk.edu.hk/ics/journal/articles/v55p001.pdf>.

22 Han, Christina. "Cremation and Body Burning in Five Dynasties China." p.11 Journal of Chinese Studies 55 (2012): n. pag. Web. 29 Apr. 2014. <http://www.cuhk.edu.hk/ics/journal/articles/v55p001.pdf>.

${ }^{23}$ Benn, James A. Burning for the Buddha: Self-immolation in Chinese Buddhism. p.14 Honolulu: U of Hawai'i, 2007. Web. 29 Apr. 2014.

${ }^{24}$ Benn, James A. Burning for the Buddha: Self-immolation in Chinese Buddhism. p.124 Honolulu: $U$ of Hawai'i, 2007. Web. 29 Apr. 2014.

25 Han, Christina. "Cremation and Body Burning in Five Dynasties China." p.11 Journal of Chinese Studies 55 (2012): n. pag. Web. 29 Apr. 2014. <http://www.cuhk.edu.hk/ics/journal/articles/v55p001.pdf>.

${ }^{26}$ Han, Christina. "Cremation and Body Burning in Five Dynasties China." p.13 Journal of Chinese Studies 55 (2012): n. pag. Web. 29 Apr. 2014. <http://www.cuhk.edu.hk/ics/journal/articles/v55p001.pdf>. 
It therefore follows that, "Self-immolation can thus be considered part of the larger process of the Sinification of Buddhism."27

What remains to be understood, then, is what texts medieval Chinese scholars were interpreting when making the decision to create a real life ritual based on scripture.

From the inception of the practice of ritual Buddhist immolation (of all kinds) there has been a corollary backlash against it, duly provided by both religious and secular authorities. The two sides of the argument are based on opposing scriptural emphases. Primarily, auto-cremators' ritual behaviors are modeled after the parable of the Medicine King, found in the Lotus Sutra. However, there is certainly also some clear influence derived from the Jataka Tales - a series of stories which purport to describe the Buddha Shakyamuni's lives leading to his enlightenment. But to what extent does the actual content of these scriptures model and even incite such behavior?

The Jataka Tales form an interesting element of the history of immolation. One of the Jataka Tales delineates the tale of the Buddha's incarnation as Prince Mahâsattva, who gave his body to be devoured by a hungry tigress. For a time, allowing oneself to be eaten was a popular method of self-sacrifice.28 As we shall see later, this method of immolation eventually would actually come to serve one of the arguments against the act of auto-cremation. However, this was not the lasting influence of the Jataka Tales on self-immolation. Repeatedly, the Jataka Tales depict great practitioners sacrificing their bodies in various fashions as a somatic method of obtaining enlightenment more quickly - quite in contrast to politically motivated immolation. However, the Prince's story would continue to hold more significant influence due to the fact that "Prince Mahâsattva's donation of his body did not occur to him spontaneously; it was inspired by the actions of bodhisattvas before him." 29 This particular story established a precedent for the concept that the very existence of previous immolators legitimated the act of immolation itself. Because the Prince claimed to be following in the footsteps of previous practitioners, "By imitating him, in their turn Chinese Buddhists became part of an infinite lineage of beings who had become buddhas through actions such as this." 30 This concept that previous practitioners' behavior could legitimate one's own is a particularly potent part of the argument for the use of immolation as a political tool.

The most influential scriptural basis for the act of immolation, however, is the story of the Medicine King. This short piece of scripture lays the groundwork for all the

\footnotetext{
27 Benn, James A. Burning for the Buddha: Self-immolation in Chinese Buddhism. p.13 Honolulu: $U$ of Hawai'i, 2007. Web. 29 Apr. 2014.

28 Benn, James A. Burning for the Buddha: Self-immolation in Chinese Buddhism. p.26 Honolulu: $U$ of Hawai'i, 2007. Web. 29 Apr. 2014.

29 Benn, James A. Burning for the Buddha: Self-immolation in Chinese Buddhism. p.26 Honolulu: $U$ of Hawai'i, 2007. Web. 29 Apr. 2014.

30 Benn, James A. Burning for the Buddha: Self-immolation in Chinese Buddhism. p.26 Honolulu: U of Hawai'i, 2007. Web. 29 Apr. 2014.
} 
basic behaviors of ritual auto-cremation. It is therefore necessary that the actions of the Medicine King found in the Lotus Sutra be examined in detail. The parable begins with the Medicine King "single mindedly seeking Buddhahood for a period of fully twelve thousand years." 31 Having done so, he attains samadhi and is able to "manifest all physical forms." 32 He believes that he has attained this ability due to having heard the Lotus Sutra and decided at once to make a sacrifice in honor of the Buddha and the Lotus Sutra itself. He enters samadhi and manifests a rain of beautiful flowers and incense. However,

"When he had finished making this offering, he rose from this samadhi and thought to himself: Though I have employed my supernatural powers to make this offering to the Buddha, it is not as good as making an offering of my own body." 33

The Medicine King then begins drinking various perfumes and fragrant oils, again for a period of 'fully twelve thousand years'. Then, he anoints his body with fragrant oils, wraps himself in heavily jeweled robes, and pours fragrant oil over his own head. He summons his transcendental powers, and sets fire to his own body. And then, "The glow shown forth, illuminating worlds equal in number to the sands of eighty million Ganges. The Buddhas in these worlds simultaneously spoke out in praise, saying:

'Excellent, excellent, good man! This is true diligence. This is what is called a true Dharma offering to the Thus Come One... Good men, this is called the foremost donation of all. Among all donations, this is most highly prized, for one is offering the Dharma to the Thus Come One'."34

The Medicine King's body burns for twelve hundred years. After death, he is reborn into 'land of the Buddha Sun Moon Pure Bright Virtue, in the household of the King Pure Virtue'. Immediately, he speaks of his intention to make another donation of his body to benefit his father. He then seeks out the Buddha, who informs him of the Buddha's own imminent death as well as The Medicine King's attendant responsibility to protect and disperse the relics of the Buddha. Upon the passing of the Buddha, the Medicine King cremates the body and makes an offering of sandalwood to the relics he has been charged with. But he determines that this is not enough, and calls for the attention of

31 "The Lotus Sutra." Trans. Burton Watson. Columbia University Press, p.206-7. n.d. Web. 29 Apr. 2014. $<$ http://blcwaterloo.fgs2.ca/sites/default/files/pdf/The\%20Lotus\%20Sutra.pdf>.

32 "The Lotus Sutra." Trans. Burton Watson. Columbia University Press, p.206-7. n.d. Web. 29 Apr. 2014. $<$ http://blcwaterloo.fgs2.ca/sites/default/files/pdf/The\%20Lotus\%20Sutra.pdfl.

33 "The Lotus Sutra." Trans. Burton Watson. Columbia University Press, p.206-7. n.d. Web. 29 Apr. 2014. $<$ http://blcwaterloo.fgs2.ca/sites/default/files/pdf/The\%20Lotus\%20Sutra.pdf>.

34 "The Lotus Sutra." Trans. Burton Watson. Columbia University Press, p.207. n.d. Web. 29 Apr. 2014. $<$ http://blcwaterloo.fgs2.ca/sites/default/files/pdf/The\%20Lotus\%20Sutra.pdfs. 
"the other bodhisattvas and great disciples, and to the heavenly beings, dragons, yakshas, and all the members of the great assembly, saying, 'You must give your undivided attention. I will now make an offering to the relics of the Buddha Sun Moon Pure Bright Virtue."'35

Having spoken thus, he burns both of his arms as a sacrifice to the relics.

"This caused the numberless multitudes who were seeking to become voice- hearers... and all of them were able to dwell in the samadhi where one can manifest all physical forms... At that time the bodhisattvas, heavenly and human beings, asuras and others, seeing that the bodhisattva had destroyed his arms, were alarmed and saddened and they said: 'This bodhisattva Gladly Seen by All Living Beings is our teacher, instructing and converting us." 36

The sutra then instructs the reader that:

"if there are those have made up their minds and wish to gain anuttarasamyak-sambodhi, they would do well to burn a finger or one toe of their foot as an offering to the Buddha towers... even if a person were to fill the whole thousand- million-fold world with the seven treasures as an offering to the Buddha... the benefits gained by such a person cannot match those gained by accepting and upholding this Lotus Sutra, even just one four-line verse of it! The latter brings the most numerous blessings of all." 37

In this way, self immolation came to be seen as an alternative to lengthy attempts at inner cultivation. This is important in several ways. The Jataka Tales emphasize that this somatic path allowed one to quickly and positively affect their own rebirth in a manner unmatched by meditative or scholarly efforts. It was a method in which to overcome attachment to one's body - a personal path to liberation. However, the Lotus Sutra shifted this concept from one of personal liberation to one of worship. The Lotus Sutra introduced the idea that one could sacrifice their body as an offering. Adding import to the action was the emphatic statement that giving up one's body was the greatest possible sacrifice. This is only bolstered by the additional idea that self-sacrifice is also capable of benefitting others. This final element is extremely important in modern immolation practices. In fact, in this section of the Lotus Sutra, the Medicine King is not referred to as such. Repeatedly, he is called "The Bodhisattva Who Is

\footnotetext{
35 "The Lotus Sutra." Trans. Burton Watson. Columbia University Press, p.208. n.d. Web. 29 Apr. 2014. $<$ http://blcwaterloo.fgs2.ca/sites/default/files/pdf/The\%20Lotus\%20Sutra.pdfs.

36 "The Lotus Sutra." Trans. Burton Watson. Columbia University Press, p.209. n.d. Web. 29 Apr. 2014. $<$ http://blcwaterloo.fgs2.ca/sites/default/files/pdf/The\%20Lotus\%20Sutra.pdfs.

37 "The Lotus Sutra." Trans. Burton Watson. Columbia University Press, p.209. n.d. Web. 29 Apr. 2014. $<$ http://blcwaterloo.fgs2.ca/sites/default/files/pdf/The\%20Lotus\%20Sutra.pdfs.
} 
Gladly Seen By All". 38 This acknowledges that his behaviors are also understood by witnesses to be of benefit to them. Also, more generally speaking, the Lotus Sutra is important because laid the blueprint for the ritual of auto-crematory self sacrifice as we know it today. Of course, there has been some historical deviation and innovation over time. But the primary elements which have been preserved in all rituals of autocremation are as follows:

1) the immolator ingests oils of some sort and takes time to prepare their body as an acceptable sacrifice,

2) the immolator wraps themselves in cloth,

3) the immolator chants a slogan or mantra before and during their immolation,

4) the immolation is performed in front of a crowd,

5) the immolation is seen as benefitting the crowd, making them 'voice hearers' and inspiring change in them for having seen the event.

What is important to mention at this point, is the element of motivation as it relates to the scriptures. As noted, the Jataka Tales are motivated towards seeking enlightenment. The Lotus Sutra, towards worship and the benefit of others. What is noticeably missing from the scriptures is any mention of politics - or even any potential application of these practices in political usage. This only lends more credibility to the idea that cultural influences are what drove the act of auto-cremation to become a literally practiced ritual. Given Yun-ha's statements about military burning being practiced at 'the sight of impending demise' and the Lotus Sutra's focus on the ability to save others, it is not difficult to see where the connection was made and the practice was adopted. Nevertheless, there is no direct historical record for the reasons that the practice began. So it is impossible to conclusively determine.

Further, it would be remiss to discuss the scriptural heritage without noting that there are also doctrinal proscriptions that seem to prohibit the act of self burning. The most frequently cited, and somewhat obvious, argument against any act of immolation is that it violates the Vinaya rules which disallow practitioners from killing or harming any sentient being. Despite the contradictory claims in the Jataka Tales and elsewhere that immolation may serve as an practice facilitating enlightenment, suicide is ultimately an act of violence and is therefore prohibited. For most practitioners, this simple statement is reason enough to abstain from the ritual of immolation.

However, there have been some interesting twists on the arguments against immolation. Martin Kovan suggests this reflects the "equivocating" nature of the

\footnotetext{
38 "The Lotus Sutra." Trans. Burton Watson. Columbia University Press, p.208. n.d. Web. 29 Apr. 2014. $<$ http://blcwaterloo.fgs2.ca/sites/default/files/pdf/The\%20Lotus\%20Sutra.pdf>.
} 
discussion about suicide in traditional Buddhist texts. ${ }^{39}$ Of particular interest was the argument that no monk should ever immolate, as they would best benefit the world by continuing to teach. In his exhaustive account of the history of immolation, Burning in the Name of the Buddha, James A. Benn cites multiple cases wherein a potential monastic immolator is told that they might better serve their purpose through other means. Immolation was best left to the lay community. The implication is that a layperson has further to go on the path to enlightenment, or perhaps has less recourse to more sophisticated and subtle means, of making progress. As such, immolation is simply an act that better serves the lay populace. This is particularly true of women. For them, it is assumed that immolation is a step towards being reborn as a man - thus allowing them to truly be able to begin walking the path. ${ }^{40}$ Here, suicide is not presented by those arguing against it as unequivocally wrong. But rather, as something that is wrong when done by a member of the sangha.

Another historical argument against immolation is that it will kill not only the immolator, but all the parasites living in their body and the insects and worms living on the ground upon which they were burning. Similarly, if one truly wished to make an altruistic action, it was better to emulate Prince Mahasattva and give your body to be eaten. When the 5th century immolator Daodu spoke of his plans to Prince Liang Wiudi, he was warned against his actions thus:

"If you really desire to create merit for beings, you ought to follow conditions in order to cultivate the Way. When your body and life become impermanent, then you should have your corpse cast into the forest. By donating it to the birds and beasts one completely perfects dânapâramitâ and also makes good karma. Because of the eighty thousand worms it is not appropriate to burn yourself. It is not something to be encouraged." 41

So, as we can see, there is some scriptural confusion surrounding the act of ritualized suicide. While it is upheld in certain circumstances, it also vilified in others as a foolish and dangerous act. Kovan may have stated this paradoxical problem best in his article, Thresholds of Transcendence: Buddhist Self- immolation and Mahāyānist Absolute Altruism. He comments:

"Across the textual spectrum, it could be said that suicide is regarded equivocally, tending to fall roughly into two uneasily opposed camps. The textual discourse

\footnotetext{
39 Kovan, Martin. "Thresholds of Transcendence: Buddhist Self- Immolation and Mahāyānist Absolute Altruism." Journal of Buddhist Ethics 20 (2013): 775-812. JSTOR. Web. 29 Apr. 2014.

40 Yun-Hua, Jan. "Buddhist Self-Immolation in Medieval China." p.251 History of Religions 4.2 (1965): 243-68. JSTOR. Web. 29 Apr. 2014.

41 Benn, James A. Burning for the Buddha: Self-immolation in Chinese Buddhism. p.4 Honolulu: $U$ of Hawai'i, 2007. Web. 29 Apr. 2014.
} 
is complex and contested, and between the Theravāda and Mahāyāna canons, despite their theoretical continuity, even mutually undermining."42

So, insofar as scriptures may be considered an influential authority regarding immolation, it would seem they lack universal agreement about the morality of the practice. Modern religious authorities, then, are left with very little cogent scholarship from which to determine the legitimacy of ritual immolation. As we shall see, this is reflected in both their ambivalent response to - and role in - the auto-cremations.

Given that Tibetan religious officials also play an authoritative role in the modern ritual of immolation, it is also important to acknowledge the historical and scriptural history of the act of self-burning in Tibet. The reality is, there is little to none. While the Lotus Sutra was popular throughout Asia, it is widely known to have been less so in Tibet. However, the Jataka Tales did have a strong influence inside the country. Nonetheless, acts of self-immolation were virtually unheard of. A limited number of acts have been noted "but the historical memory of such practices had more or less faded from Tibetan memory, being only recorded in ancient texts." 43 So, Tibetans were simply not engaging with the texts in the same way that their Chinese counterparts were. Indeed, the evidence does seem to support that Benn is correct in asserting the integration of auto-cremation was an element of the 'Sinicization' of Buddhism.

Having understood how the Chinese came to adopt auto-crematory acts, it remains to be explicated the manner in which they enacted the ritual. Many elements of the very first auto-cremations are still in place in the modern procedure of the ritual. Understanding the way third party authorities shape the behaviors of the ritual necessarily must begin with understanding the role of governmental and religious officials in developing them.

\section{Elements of Early Immolation Rituals}

In order to best understand what is at play in modern Tibetan auto-cremation, we must first establish what is unique about it - and what isn't. Generally speaking, immolations have always occurred in waves - one seems to 'spark' others. Kelly refers to this as the 'Werther Effect', a psychological phenomena frequently noted in different groups of people all over the world. However, Kelly notes that the Buddhist immolators' motivation for their actions is very unique from other forms of group suicide - in that they seek to benefit others and not solely those who plan to die. ${ }^{44}$ This is important because since the fifth, there has never been a century which passed without a cycle of

\footnotetext{
42 Kovan, Martin. "Thresholds of Transcendence: Buddhist Self- Immolation and Mahāyānist Absolute Altruism." p.780 Journal of Buddhist Ethics 20 (2013): 775-812. JSTOR. Web. 29 Apr. 2014.

43 Shakya, Tsering. "Self Immolation: The Changing Language of Protest in Tibet." Revue D'Etudes Tibétaines (n.d.): n. pag. PDF Print.

44 Kelly, Brendan D. "Self-immolation, Suicide and Self-harm in Buddhist and Western Traditions." p.311 Transcultural Psychiatry 48 (2011): n. pag. Sage Publications. Web. 2 Dec. 2013. <http:// tps.sagepub.com.proxy.its.virginia.edu/content/48/3/299.full.pdf>.
} 
immolations. Each were undertaken in response to the perceived threat of Buddhism. 45 The fact that these rituals function in waves is important. First, it is again reminiscent of functioning in tandem, as an army does. Second, the implication is there that acts of auto-cremation are most politically efficacious in aggregate. One single death is rarely capable of exacting change alone. Rather, one death has the significance of inspiring others - which in turn begins the Werther Effect. This concept that volume makes the deaths more politically effective is present from the very first cycle of immolations - in which many lives were lost before 'anti-Buddhist measures' ceased to be enforced. ${ }^{46}$ Cycles of Buddhist immolations are necessarily extant to meet specific goals. With each cycle, the ritual changes to reflect those goals. This is in response to the pressures of secular and religious officials. The influence of outside authorities figures has consistently forced the ritual to evolve - from the very first auto-cremation just before the fifth century, until those in April, 2014.

\section{Establishing the Ritual: Procedural Behaviors at the Inception of the Ritual}

The first ever known auto-cremator was Fayu, who went through ritual immolation in 396. His "premeditated and publicly staged performance" represented an innovation that was heretofore nonexistent - the literal acting out of the act of auto-cremation. ${ }^{47}$ It is noted by Benn that his autobiographies express his "constant aspiration...to follow the traces of the Medicine King and to burn his body in homage to the Buddha." 48 The first ever recorded auto-crematory ritual contained the following elements.

Fayu begins his ritual by going to inform the 'illegitimate Prince of Jin, Yao Xu' of his intentions. Yao Xu attempts to convince Fayu not to burn himself alive. Nonetheless, Fayu 'was not to be put off'. He readies his body by swallowing incense and wrapping himself in cloth. In front of a crowd of both lay and monastic witnesses, he recites the chapter on the Medicine King. And at the end of his recitation, he sets himself alight. Those who witnessed his death were said to be "full of grief and admiration." 49

There are, of course, some significant elements about the way that this act was recorded. Namely, no inspiration is listed as to why he chose this method of immolation. Nor is it made clear why he felt that he must ask permission from an authority figure

\footnotetext{
45 Benn, James A. Burning for the Buddha: Self-immolation in Chinese Buddhism. Honolulu: U of Hawai'i, 2007. Web. 29 Apr. 2014.

46 Benn, James A. Burning for the Buddha: Self-immolation in Chinese Buddhism. p.40 Honolulu: $U$ of Hawai'i, 2007. Web. 29 Apr. 2014.

47 Benn, James A. Burning for the Buddha: Self-immolation in Chinese Buddhism. p.33 Honolulu: $U$ of Hawai'i, 2007. Web. 29 Apr. 2014.

48 Benn, James A. Burning for the Buddha: Self-immolation in Chinese Buddhism. p.33 Honolulu: $U$ of Hawai'i, 2007. Web. 29 Apr. 2014.

49 Benn, James A. Burning for the Buddha: Self-immolation in Chinese Buddhism. p.34 Honolulu: U of Hawai'i, 2007. Web. 29 Apr. 2014.
} 
before engaging in the act itself. However, Benn states that, "this precaution would have been self- evident in medieval China, where it was dangerous to do much without permission from the authorities." 50 Nonetheless, he was clearly not truly seeking permission - else he would have obeyed Yao Xu. More likely then, he simply wanted the authority figure to be aware of his plans. He wanted to be seen.

What is interesting however, is that it seems that Yao Xu was considered illegitimate because he was not Han Chinese. The area in North China where Fayu lived, Puban, had come under the control of invaders. ${ }^{51}$ So while Fayu's act was not recorded as one of outright political protest, auto-cremation does seem to represent an innovation that took place under times of political duress. Around the year 400, Buddhists were becoming more involved in Chinese politics - translation of texts had come under the power of the state and 'rulers cultivated the power of monks in a more systemic way than had been the case in earlier centuries." 52 And so it is important to make note that he made it a point to make his intentions known to his 'illegitimate' leader - and then defied that leader's wish that he not immolate. Further, he performed his act in front of his fellow citizens - who may well have known that he was defying $\mathrm{Xu}$ through his actions. Unlike those who went before him, he did not simply lie in a forest and allow himself to become someone's lunch. He staged a performance. He was unquestionably trying to inspire 'grief and admiration'.

As such, this very first immolation laid the groundwork for the ritual of autocremation. Benn states that, "All of the elements that were to characterize autocremation in the fifth and sixth centuries - the involvement of secular powers, preparation of the body with incense or oil, the chanting of the text, and the public nature of the final act-are already present in this biography from 396." ${ }^{53}$

It would be 55 years until the next recorded auto-cremation. Nonetheless, the fifth century saw a large rise in immolation activities. These led to what Benn refers to as "classic elements of fifth century auto-cremation". ${ }^{54}$ This refers to the preparation of a vow of intent, chanting before and during immolation, and public performance of the immolation in front of a gathered crowd. Also notable, since their fifth century roots, cycles of self immolation have always included diverse groups of actors. As Yun-Ha points out, this was an action which was undertaken by both lay and monastic, male

\footnotetext{
50 Benn, James A. Burning for the Buddha: Self-immolation in Chinese Buddhism. p.34 Honolulu: $U$ of Hawai'i, 2007. Web. 29 Apr. 2014.

51 (Benn, Multiple Meanings of Buddhist Self-Immolation in China - A Historical Perspective, p.204)

52 Benn, James A. Burning for the Buddha: Self-immolation in Chinese Buddhism. p.34 Honolulu: U of Hawai'i, 2007. Web. 29 Apr. 2014.

53 Benn, James A. Burning for the Buddha: Self-immolation in Chinese Buddhism. p.34 Honolulu: U of Hawai'i, 2007. Web. 29 Apr. 2014.

${ }^{54}$ Benn, James A. Burning for the Buddha: Self-immolation in Chinese Buddhism. p.40 Honolulu: $U$ of Hawai'i, 2007. Web. 29 Apr. 2014.
} 
and female. ${ }^{5}$ Further, during this time it was also established that an auto-crematory ritual could not be undertaken without first attempting peaceful protests. ${ }^{56}$ These factors remain in place today.

However, circumstances of and motivations for auto-cremation have changed since this first wave of auto-cremations. In each case, the fifth century act was undertaken at the perceived 'sight of impending demise' of Buddhist practice. Yet modern practices may resemble something more akin to a hybrid of motivations. They share the desire to protect Buddhism, as in the tradition of religious self-immolators. Yet, they also are serving to protect secular entities - such as governmental autonomy and educational agency - which is more reflective of the military self-immolations occurring concurrent with those of Fayu and those who followed him.

During the fifth century, the use of relics was established in the ritual of immolation. Relics were used in one of two ways. Either the immolator would choose to die in front of relics, or they would choose to leave relics behind as a token of remembrance for their witnesses. ${ }^{57}$ By performing a cremation in front of a famous landmark, an immolator was better able to create a lasting image in the minds of witnesses. Similarly, by leaving behind relics, they were trying to ensure that their story would be retold. In fact, the role of relics became so important in the ninth century that the bodies of cremators were treated as holy relics. Cults formed around the enshrined bodies, and practitioners came to believe that they would see worldly benefit by praying to the dead cremators. ${ }^{58}$ By the tenth century, it was believed that relics could not only be used in ritual - but that the ritual itself could produce them. "Self-immolators themselves were commonly depicted as being able to produce relics in vast quantities, sometimes spontaneously while still alive."59 These relics were displayed with bodies and treated with great reverence. 60

Relic production is an element of ritual which is particularly potent in the modern Tibetan immolation. Physically manifested relics are actively produced in the form of photos or videos, and then their dissemination becomes the primary aim of the ritual.

55 Yun-Hua, Jan. "Buddhist Self-Immolation in Medieval China." p.251 History of Religions 4.2 (1965): 243-68. JSTOR. Web. 29 Apr. 2014.

56 Yun-Hua, Jan. "Buddhist Self-Immolation in Medieval China." p.252 History of Religions 4.2 (1965): 243-68. JSTOR. Web. 29 Apr. 2014.

57 Benn, James A. Burning for the Buddha: Self-immolation in Chinese Buddhism. p.130 Honolulu: U of Hawai'i, 2007. Web. 29 Apr. 2014.

58 Benn, James A. Burning for the Buddha: Self-immolation in Chinese Buddhism. p.130 Honolulu: $U$ of Hawai'i, 2007. Web. 29 Apr. 2014.

59 Benn, James A. Burning for the Buddha: Self-immolation in Chinese Buddhism. p.210 Honolulu: U of Hawai'i, 2007. Web. 29 Apr. 2014.

60 Benn, James A. Burning for the Buddha: Self-immolation in Chinese Buddhism. p.210 Honolulu: $U$ of Hawai'i, 2007. Web. 29 Apr. 2014. 
The most important element of early immolations, however, as far as Tibetan auto-cremation is concerned, reveals the massive shift that the role of secular authority has undergone in the ritual in modern times. Frequently, medieval Chinese local authorities would join the community in coming to view the ritual of the immolation. In fact, more often than not fifth century immolators seemed to be acting "in collusion with local authorities".61 Typically, an auto-cremation normally followed a set pattern of interactions with the government before the ritual began. A monk named Tao-chi set the standard that potential immolators must always first attempt non-violent protest. 62 Should this fail, the protestor would seek permission from a perceived authority normally a government leader. This request would inevitably be denied. The immolator would vow to continue with their plans in spite of the denial. And yet the authority would come to view the death, rather than actively try to prevent its occurrence. James Benn demonstrates many cases which follow this pattern in his book, Burning for the Buddha. This is important because, historically, official castigation of immolation practices was usually perfunctory. Leaders might refuse to give their blessing, and yet the authority against which an immolator was demonstrating did not interfere with the ritual itself. This implies that authorities have always had a hand in crafting the images produced by those who choose to immolate. In the fifth century, this meant that the citizenry bore witness to their government officials' passivity in the face of a ritualized suicide. Michelle Murray Yang wrote that when witnesses see an immolation photo, they necessarily see those who drove person to immolate. ${ }^{63}$ In the fifth century, this would have been literally true. The emotional impact of the scene would have been a result of not only the death, but the physical presence of those who could have prevented it.

This is also of particular import because although political auto-cremations began in 396, none are recorded as having been successful until that of Ta-chih in 579.64 This means that for a period of nearly two centuries, hundreds of people burned themselves to death while government officials watched. The protested policies remained unmoved. The reasons for this behavior are not recorded. It is unclear if officials took part in the ritual in this way to demonstrate power - wanting to be seen unmoved in the face of this protest. But perhaps more likely, allowing the rituals to go forward was acting as a pressure release. By sanctioning the protest of one individual, perhaps it was hoped that this would help avoid group acts of violence. Again, reasons for this behavior are unrecorded, so we are left with only speculation. However, one thing is clear. Modern

\footnotetext{
61 Benn, James A. Burning for the Buddha: Self-immolation in Chinese Buddhism. p.41 Honolulu: $U$ of Hawai'i, 2007. Web. 29 Apr. 2014.

62 Yun-Hua, Jan. "Buddhist Self-Immolation in Medieval China." p.252 History of Religions 4.2 (1965): 243-68. JSTOR. Web. 29 Apr. 2014.

63 Murray Yang, Michelle. "Still Burning: Self-Immolation as Photographic Protest." (n.d.): n. pag. All Academic Research. Web. 1 Dec. 2013. <http://citation.allacademic.com//meta/ p_mla_apa_research_citation/1/9/1/2/7/pages191275/p191275-1.php>.

64 Yun-Hua, Jan. "Buddhist Self-Immolation in Medieval China." p.252 History of Religions 4.2 (1965): 243-68. JSTOR. Web. 29 Apr. 2014.
} 
Tibetans frequently speak of their acts of immolation as 'acting as a lamp'.65 This concept is presaged in the medieval immolations in that auto-cremators were allowed to shine a light on Buddhist complaints regarding the actions of secular authority.

This set important precedents for modern immolators in regard to being noticed by those they were protesting against. Clearly, lack of initial political success is irrelevant to the legitimacy of this practice. From its inception, self-immolation had at least one thing in common with other forms of warfare. If it wasn't successful the first day, that did not mean the war was over. Further, the fact that there were successful immolations 66 - those which achieved the aim of reversing 'anti-Buddhist measures' could only have contributed to the view of immolations as being more successful when performed in volume. This explains why Buddhist self-burning is unique in relation to Kelly's Werther Effect. Cycles of immolation are not suicide copycatting, the immolators are more likely to effect their aim of benefitting others if they auto-cremate in large numbers. ${ }^{67}$

\section{Conclusions}

As has been demonstrated, there is a long history of Buddhist auto-cremation in China. A canonical history that holds up the practice as not only effective, but also laudable. As a practice that will not only effect worldly change, but free the immolator from the binds of their samsaric existence. Knowing this, it is impossible to consider that either medieval or modern self-immolators were simply mad. Far from crazed, autocremations have seemingly often represented calculated behavior. From fifth century forward, auto-crematory immolation activities have been nothing short of ritualized Buddhist warfare, to be "practiced at the sight of impending demise" of the practice of Buddhism itself. 68

\section{Modern Tibetan Auto-cremation}

It does represent a large logical jump to move from medieval Chinese ritual practices to the modern practices of another culture. Indeed, there is no direct historical record of how Tibetans came to adopt the practice. However, the two are certainly connected. As stated, the cycles of immolations have continued in China in every

\footnotetext{
65 Blake, Matt. "A Serene Smile for Her Last Picture: Haunting Story of Nun, 17, Who Scrawled Final Message on Her Hand and Then Set Herself on Fire in Bid to Free Tibet." Mail Online. UK Daily Mail, 4 Dec. 2012. Web. 29 Apr. 2014. <http://www. dailymail.co.uk/news/article-2242808/Last-words-SangayDolma-Tibetan-nun-set-protest-We-warriors-snow-mountain.html>.
}

66 Yun-Hua, Jan. "Buddhist Self-Immolation in Medieval China." p.252 History of Religions 4.2 (1965): 243-68. JSTOR. Web. 29 Apr. 2014.

67 Kelly, Brendan D. "Self-immolation, Suicide and Self-harm in Buddhist and Western Traditions." p.311 Transcultural Psychiatry 48 (2011): n. pag. Sage Publications. Web. 2 Dec. 2013. <http:// tps.sagepub.com. proxy.its.virginia.edu/content/48/3/299.full.pdf>.

68 (Han, Body Burning in Five Dynasties China, p.11) 
century since their inception. The last Buddhist immolations to take place previous to the Tibetan auto-cremations were in 1911, during the Xinhai Revolution against the Qing Dynasty. 69 Yet this 1911 Buddhist immolation is likely not the scenario by which Tibetans were inspired. There are two far more probable sources of this inspiration.

The most likely candidate is the politically successful auto-cremation of Thich Quang Duc. This immolation is quite famous. And given that the first ever Tibetan autocremation occurred in exile, it is not unthinkable the Duc was the inspiration. For example, Thupten Ngodup - the original Tibetan auto-cremator - produced a final vow that was not entirely dissimilar to that of Thich Quang Duc's. ${ }^{70}$ It stressed the importance of sacrifice and the righteousness of Buddhist principles. ${ }^{71}$ So while Ngodup never directly recorded Duc as his inspiration, he did leave behind some evidence to suggest that he was aware of him.

Duc, in his turn, was explicitly inspired by the Chinese auto-cremators of the past. Benn states:

"It is known, for example, that Thich Quang Duc, the scholarly Vietnamese monk who burned himself to death in 1963 to protest the South Vietnamese government's treatment of Buddhists, was conversant not only with the scriptural sources for auto-cremation-he chanted the Lotus Sutra every day-but also with the history of Chinese auto-cremators who had gone before him."72

A second case which may represent the connection between medieval Chinese and modern Tibetan auto-cremation is the auto-crematory deaths of several member of a group known as Falun Gong. In January of 2001, five member of the Falun Gong auto-cremated in Tiananmen Square as a response to the repression of qi gong healing practices. The PRC responded in kind, and "Self-immolation became the centrepiece of the government's continuing [anti-Falun Gong] propaganda campaign."73 So while Benn has suggested that Thupten Ngodup was the inspiration for the first Tibetan autocremation inside of Tibet ${ }^{74}$, it doesn't seem out of the question that an anti-immolation

\footnotetext{
69 Benn, James A. Burning for the Buddha: Self-immolation in Chinese Buddhism. p.XXXIII Honolulu: U of Hawai'i, 2007. Web. 29 Apr. 2014.

70 The Buddhist Channel. N.p., n.d. Web. 30 Apr. 2014. <http\%3A\%2F\%2Fwww.buddhistchannel.tv \%2Findex.php\%3F\%09id\%3D70\%2C11491\%2C0\%2C0\%2C1\%2C0\%23.UzndLxY0Pzl>.

71 Canada Tibet Committee, n.d. Web. 30 Apr. 2014. <http://www.tibet.ca/en/newsroom/wtn/archive/old? $\mathrm{y}=1998 \& \mathrm{~m}=4 \& \mathrm{p}=29$ 4) $>$.

72 Benn, James A. "Burning For The Buddha." Editorial. p.1, n.d. Web. 29 Apr. 2014. <http:// robprideaux.com/dev_blog/wp-content/uploads/2013/11/immolation1.pdf>.

73 Biggs, Michael. "Self-Immolation in Context, 1963-2012." p.147-8 Revue D’Etudes Tibétaines 25 (2012): 143-50. Web. 30 Apr. 2014.
}

74 Benn, James A. "Burning For The Buddha." Editorial. p.1, n.d. Web. 29 Apr. 2014. <http:// robprideaux.com/dev_blog/wp-content/uploads/2013/11/immolation1.pdf>. 
propaganda campaign might also have gotten the attention of dissidents inside Tibet as an action that would firmly hold the attention of the Chinese government.

Both of these items represent a few degrees of separation from original Chinese auto-crematory practices. But as we are unable to communicate with the deceased, it is impossible to know their direct inspiration if it is not clearly recorded. However, these two cases do represent a compelling connection for inspiration between medieval and modern practices. It does seem that, in a twist of ultimate irony, the Tibetans have undertaken a Chinese method of protesting the Chinese government.

So now that a history of scripture, ritual procedure, and potential modes of adoption have been examined, all that remains is to understand the ritual in its modern form. Necessarily, the role of secular authority plays an important role in the adaptation of the ritual into the Tibetan method.

The Role of Chinese Governmental Authority in Tibetan Auto-Cremation

The most clear cut factor driving the auto-cremations is the loss of Tibetan sovereignty. It is widely accepted that the auto-cremations are in protest of the conditions under Chinese rule - specifically the suppression of Tibetan culture and language, systematic ethnic bias and racism, violent suppression of dissent, state control of religion, and the exile of the Dalai Lama. ${ }^{75}$ This is made clear in the slogans of immolators. ${ }^{76}$ The role of Chinese government authority in the ritualized immolation is that of the antagonist. This is important in several ways. First, it is because of Chinese policy that Tibetans feel that their culture and religion is under the threat of eradication which is the reason for engaging in immolation in the first place. This is made clear in the final words of many of the immolators, as well as official statements given by the

\footnotetext{
75 Davis, Carlo. "Dalai Lama: Tibetan Self-Immolations Have Little Effect, But Are Understandable." The Huffington Post. TheHuffingtonPost.com, 13 June 2013. Web. 11 Dec. 2013. <http:// www.huffingtonpost.com/2013/06/13/dalai-lama-tibetan-self-immolations n 3432498.html>.
}

Sangay, Lobsang. "Why Tibet Is Burning..." Tibetan Policy Insitute, 2013. Web. 30 Apr. 2014. <http:// tibet.net/wp-content/uploads/2013/02/Whitepaper-Final-PDF.pdfs.

Smith, Christopher H., and Sherrod Brown. United States. Congressional Executive Committee on China. Cong. Rept. N.p., 23 Dec. 2011. Web. 1 Dec. 2013. <http://permanent.access.gpo.gov/gpo19336/CECCSpecial-Report-Tibetan-Monastic-Self-Immolations-12-23-11.pdf

76 Blake, Matt. "A Serene Smile for Her Last Picture: Haunting Story of Nun, 17, Who Scrawled Final Message on Her Hand and Then Set Herself on Fire in Bid to Free Tibet." Mail Online. UK Daily Mail, 4 Dec. 2012. Web. 29 Apr. 2014. <http://www. dailymail.co.uk/news/article-2242808/Last-words-SangayDolma-Tibetan-nun-set-protest-We-warriors-snow-mountain.html>. 
United States government, and the Central Tibetan Administration in Exile. ${ }^{77}$ Some of the reasons given for the perception that Tibetan Buddhist practice is endangered include: financial sanctions against monasteries, state violence against or incarceration of monks or laypersons loyal to the Dalai Lama, outlawing of elements of Tibetan cultural identity - such as language, the Tibetan flag, or education on Tibetan history, ${ }^{78}$ and the disappearance of the Panchen Lama in 1995. ${ }^{79}$ This final 'threat' to the future of Buddhism is the most complex. And also the most concrete fashion in which the future of traditional Tibetan Buddhism seems to be be under threat of eradication inside Tibet.

According to Tibetan practices previous to the Chinese takeover, the largest polity on the plateau involved a complex religious-aristocratic partnership in which the Dalai Lama and the Panchen Lama were the highest religious authorities. Both were recognized as the highest Bodhisattvas by the Geluk sect, which held the political reigns - the Panchen Lama is considered to be the incarnation of Amitabha, the Buddha of Boundless Light and the Dalai Lama is thought to be the incarnation of Avalokitesvara, the Buddha of Compassion. The two, through successive reincarnations, ideally were intended to act as "tutor and disciple to each other, and after the death of one tradition held that the other would play a key role in identifying his reincarnation," though in reality there were important regional tensions between the Central and Western regions in which each was respectively based. 80 In keeping with this tradition, the current Dalai Lama recognized six year old Gedhun Choekyi Nyima as the 11th Panchen Lama in 1995. The boy was six years old at the time. Shortly after this recognition, the boy and his family were taken into custody by Chinese officials on the grounds that he was "at risk of kidnapping by Tibetan separatists". ${ }^{81}$ He has not been seen again since then. Despite many calls for clarification on his current whereabouts by both international governments and NGOs, Sikyong Lobsang Sangay stated on March 5th, 2014 that the CTA currently has no knowledge of the well being or location of Gedhun Choekyi

\footnotetext{
77 Sangay, Lobsang. "Why Tibet Is Burning..." Tibetan Policy Insitute, 2013. Web. 30 Apr. 2014. <http:// tibet.net/wp-content/uploads/2013/02/Whitepaper-Final-PDF.pdf>.
}

Smith, Christopher H., and Sherrod Brown. United States. Congressional Executive Committee on China. Cong. Rept. N.p., 23 Dec. 2011. Web. 1 Dec. 2013. <http://permanent.access.gpo.gov/gpo19336/CECCSpecial-Report-Tibetan-Monastic-Self-Immolations-12-23-11.pdf

78 Sangay, Lobsang. "Why Tibet Is Burning..." Tibetan Policy Insitute, 2013. Web. 30 Apr. 2014. <http:// tibet.net/wp-content/uploads/2013/02/Whitepaper-Final-PDF.pdf>.

79 Blake, Matt. "A Serene Smile for Her Last Picture: Haunting Story of Nun, 17, Who Scrawled Final Message on Her Hand and Then Set Herself on Fire in Bid to Free Tibet." Mail Online. UK Daily Mail, 4 Dec. 2012. Web. 29 Apr. 2014. <http://www. dailymail.co.uk/news/article-2242808/Last-words-SangayDolma-Tibetan-nun-set-protest-We-warriors-snow-mountain.html>.

80 Hilton, Isabel. The Search for the Panchen Lama. p.7 New York: W.W. Norton, 2000. Print.

81 "Gyaincain Norbu." Chinese Buddhist Encyclopedia. N.p., n.d. Web. 30 Apr. 2014. <http:// www.chinabuddhismencyclopedia.com/en/index.php?title=Gyaincain Norbu>. 
Nyima. ${ }^{82}$ Despite providing no evidence to support the claim, Chinese authorities continue to reiterate that Nyima is in good health and 'does not wish to be disturbed'. .83

In the weeks following the disappearance of Nyima, the Chinese government installed another young Tibetan boy as Panchen Lama, namely Gyaincain Norbu. Norbu currently also serves as Vice President of the Buddhist Association of China and a member of the National Committee of the Chinese People's Political Consultative Conference. ${ }^{84}$ Norbu has made it clear that he "resolutely oppose(s) all activities to split the country and undermine ethnic unity." 85 As such, his role in choosing the next Dalai Lama is of great concern for Tibetans who seek to protect both the unique Tibetan identity, as well as the traditional Buddhist system of reincarnation and leadership.

The conflict regarding the future of religious authority inside China's Tibet is made all the more pressing given the age of the current Dalai Lama. At 78, the time is not so far away that the search for the Fifteenth Dalai Lama will have to begin. The current Dalai Lama has stated that there are many possibilities for his future reincarnation - including that there may not be one at all. But he stresses that the choice will not be in the hands of any political figures. ${ }^{86}$ Ostensibly, this includes Norbu - whose position on the NCCPPCC makes him a member of the Chinese government. As the exiled Dalai Lama does not recognize the legitimacy of Norbu as Panchen Lama, ${ }^{87}$ it appears that upon his death the Dalai Lama has no clear successor while his reincarnation is located and comes to maturity. This makes the suggestions that the line of Dalai Lamas may end with Tenzin Gyatso all the more troubling for Tibetans.

So much uncertainty about the future of religious leadership absolutely fits the model of medieval immolation as practiced at 'the impending demise' of Buddhism. Especially when coupled with the destruction of monasteries and the attempts to suppress Tibetan ethnic identity. Accompanied by systematic discrimination in educational and economic domains, there can be no question as to the role of the Chinese government in motivating the immolations.

\footnotetext{
82 Sangay, Lobsang. "Challenges and Opportunities for Tibetan Democracy in Exile." National Endowment for Democracy, Washington, DC. 5 Mar. 2014. Speech.

83 "Free the Panchen Lama." N.p., n.d. Web. 30 Apr. 2014. <http://www.freepanchenlama.org/>.

84 "Gyaincain Norbu." Chinese Buddhist Encyclopedia. N.p., n.d. Web. 30 Apr. 2014. <http:// www.chinabuddhismencyclopedia.com/en/index.php?title=Gyaincain Norbu>.

85 "Gyaincain Norbu." Chinese Buddhist Encyclopedia. N.p., n.d. Web. 30 Apr. 2014. <http:// www.chinabuddhismencyclopedia.com/en/index.php?title=Gyaincain Norbu>.

86 Gentilviso, Chris. "Dalai Lama Reincarnation: Tibetan Spiritual Leader Says He Will Spell Out Own Details." The Huffington Post. TheHuffingtonPost.com, 24 Sept. 2011. Web. 30 Apr. 2014. <http:// www.huffingtonpost.com/2011/09/24/dalai-lama-reincarnation n 978990.html>.
}

87 "Gyaincain Norbu." Chinese Buddhist Encyclopedia. N.p., n.d. Web. 30 Apr. 2014. <http:// www.chinabuddhismencyclopedia.com/en/index.php?title=Gyaincain Norbu>. 
As a result, it is would be remiss to imply that the Tibetan immolations are purely about reincarnate lineages and protecting Buddhism. When a Tibetan auto-cremates, they a frequently heard calling for freedom. So, when the phrase 'impending demise' is used in relation to modern Tibetan rituals of auto-cremation, it must not be forgotten that this means the demise of Tibetan culture as a whole. In Tibet, Tibetan citizens believe themselves to be fighting for the ability to survive financially, be educated, live as equals, and have human rights. This is a fight for political agency as well as well as religious freedom, and that point must not be lost. This is significant because in this secular aim, the Tibetans are actually again mirroring a ritual which shows more connection with the medieval military auto-cremations than one might expect. Here, they are fighting for autonomy. It is clear that the auto-cremation is again serving to connect the auto-cremator with the land, in the sense that they believe themselves to be serving their home. And further, that it is strengthening the bonds that their opposition hoped to weaken - namely those of cultural identity. So, in this way, the warlike aspects of this ritual cannot be ignored.

In this role as foil, Chinese authorities have also played a role in engendering innovations in the ritual performance itself. It no longer takes places as a grandly staged public event. The PRC has outlawed immolation and gone to great lengths to prevent its continued practice. ${ }^{88}$ Where once Chinese officials increased the efficacious power of the image of immolation deaths by being present, the modern role of authority in the production of the ritual is quite different. Modern Tibetan immolations take place in dynamic motion caused by the fact that Chinese authorities are not sitting idly by letting them occur. Potential immolators face two very different circumstances regarding secular authority from their predecessors.

First, auto-cremators face the very real likelihood that those around them will try to put them out. This was never an issue in the past. The spectacle was always allowed to go forward. In the case of auto-cremators inside China, it is frequently reported that police quite literally beat the fire out of the Tibetan in question. ${ }^{89}$ In fact, Tapey - the first Tibetan ever to auto-cremate inside China, was shot by police while he was still on fire. ${ }^{90}$ As a result of this type of interference, the method of auto-cremation has been adapted to ensure success. Namely, it happens quickly and without warning. Some

\footnotetext{
88 "'Absurd and Terrifying' New Regulations Escalate Drive to Criminalize Self-immolations by Targeting Family, Villagers, Monasteries." International Campaign for Tibet, 24 Feb. 2014. Web. 30 Apr. 2014. <http $\% 3 \mathrm{~A} \% 2 \mathrm{~F} \% 2 \mathrm{Fwww}$.savetibet.org\%2Fabsurd-and-terrifying-new-regulations-escalate-drive-to-criminalizeself-immolations-by-targeting-family-villagers-monasteries $\% 2 \mathrm{~F}>$.
}

89 Savetibet.org. International Campaign for Tibet, 16 Apr. 2014. Web. 29 Apr. 2014. <http:// www.savetibet.org/resources/fact-sheets/self-immolations-by-tibetans/>.

90 Tsering, Buchung K. "Man on Fire." Himal Mag. N.p., 10 Feb. 2012. Web. 30 Apr. 2014. <http:// old.himalmag.com/component/content/article/5006-man-on-fire.html>. 
cases of self-immolators report that individuals wrap themselves in barbed wire. ${ }^{91}$ This way others are less able to tamp down the flames and the ritual protest can last longer. It also provides more opportunity for photos and videos to be taken. The image of a running immolator is one built as much out of necessity as it is metaphor.

Taking the perspective of Yang:

"In the case of an individual utilizing self-immolation as a means of political or social protest, the destruction of himself is a visual representation of violence committed by an "other." "92

In other words, the images formed by auto-cremation are relics produced not only as reminders of the dead - but also as an indictment of those whose perceived cruelties led to their death. So while medieval immolators' final scene depicted them as diametrically opposed to their leaders, they were, however, in static relationship at the immolation site, Tibetan immolators present themselves as being hounded. They want witnesses to see them running from Chinese authorities. Even outside of China, the far fewer exile Tibetan immolators run down streets - as if being chased. 93

Similarly, given the hurried nature of the ritual, the countenance of autocremators has changed. Unlike Fayu or Ta-chih, Tibetan immolators are not at peace in the images they are creating. Whereas both the story of the Medicine King and the examples of medieval immolators depict one who is calm in the face of great pain demonstrating their mastery over their bodies - Tibetan immolators' faces clearly show suffering, fear, and imminent death. Illustrating Yang's point, it seems that Tibetans are not depicting themselves as religious masters but rather as sufferers running for their lives. Indeed, it seems that the immolators do intend to be perceived this way. Internationally, it does appear that they are viewed in this fashion. However, given the atmosphere surrounding the dissemination of photos, it is actually unlikely that the Han Chinese populace is even necessarily aware anytime that an immolation occurs.

To explain, in addition to increasing the speed and changing the tone of the ritual, the Chinese government plays another important role in immolations that occur inside China. Immolators now undertake their ritual with the knowledge that those around them will suffer the consequences of their actions. This is something of which there is no historical record. As it stands today, the PRC has officially enacted the

91 Savetibet.org. International Campaign for Tibet, 16 Apr. 2014. Web. 29 Apr. 2014. <http:// www.savetibet.org/resources/fact-sheets/self-immolations-by-tibetans/>.

92 Murray Yang, Michelle. "Still Burning: Self-Immolation as Photographic Protest." (n.d.): n. pag. All Academic Research. Web. 1 Dec. 2013. <http://citation.allacademic.com//meta/ p_mla_apa_research_citation/1/9/1/2/7/pages191275/p191275-1.php>.

93 "Tibetan Activist Dies After Setting Himself Alight." The Huffington Post UK. N.p., 28 Mar. 2012. Web. 30 Apr. 2014. <http://www.huffingtonpost.co.uk/2012/03/28/tibetan-protester-jamphel-yeshi-dies-chinatibet n 1384446.html\%29>. 
"Strike Hard Campaign", aimed at preventing further immolations. ${ }^{94}$ Article Three of the document outlines very clearly the adversarial role the government has taken regarding the immolations: "If there is a self-immolation, the local government will attack your family, village, and monastery." 95 The families of immolators face 're-education', jail, and even torture in response to the death of their loved one. Similarly, entire towns can be made to suffer for having 'allowed' an immolation to happen. This usually means having government assistance or rations cut off in a city wherein someone has autocremated. Monasteries which were home to monks or nuns who auto-cremate also see sanctions on their activities as well. ${ }^{96}$ Following the auto-crematory of death of Sangay Dolma,

"a five-point notice...[was issued] in eastern Tibet, giving stern orders to local officials to punish self-immolators and their families; even those who had offered condolences and prayers to the bereaved family members and relatives. The notice further announced the cancellation of government aid to families of selfimmolators as well as development projects in villages where similar protests have taken place.... Government authorities in the region.. also collect[ed] signed statements from each household confirming that they will not self-immolate. Refusal to sign such statements attract[ed] immediate detention." 97

In further attempts to stem the efficacy of rituals which have already taken place, city infrastructures are manipulated to keep any photos from being distributed. For example, with the auto-cremation of a nun called Dolma on March 29th, 2014, it was reported that "Security was tightened in the monastery and county town, with internet connections blocked and mobile phone connections cut." 98

\footnotetext{
94 "China Announces Unprecedented Harsh Measures to Deter Self-immolations in Tibet's Dzoege County." Tibetan Centre for Human Rights and Democracy. N.p., 14 Feb. 2014. Web. 30 Apr. 2014. $<$ http://www.tchrd.org/2014/02/china-announces-unprecedented-harsh-measures-to-deter-selfimmolations-in-tibets-dzoege-county/>.

95 "China Announces Unprecedented Harsh Measures to Deter Self-immolations in Tibet's Dzoege County." Tibetan Centre for Human Rights and Democracy. N.p., 14 Feb. 2014. Web. 30 Apr. 2014. $<$ http://www.tchrd.org/2014/02/china-announces-unprecedented-harsh-measures-to-deter-selfimmolations-in-tibets-dzoege-county/>.
}

96 "'Absurd and Terrifying' New Regulations Escalate Drive to Criminalize Self-immolations by Targeting Family, Villagers, Monasteries." International Campaign for Tibet, 24 Feb. 2014. Web. 30 Apr. 2014. <http $\% 3 \mathrm{~A} \% 2 \mathrm{~F} \% 2 \mathrm{Fwww}$.savetibet.org\%2Fabsurd-and-terrifying-new-regulations-escalate-drive-to-criminalizeself-immolations-by-targeting-family-villagers-monasteries $\% 2 \mathrm{~F}>$.

97 "17-year-old Self-immolator's Last Note Calls for the Dalai Lama's Return and Tibet's Independence." Phayul.com. N.p., 28 Nov. 2012. Web. 30 Apr. 2014. <(http://www.phayul.com/news/article.aspx? id $=32557>$.

98 "Tibetan Nun Sets Fire to Herself outside Monastery in First Self-immolation in Bathang." International Campaign for Tibet. N.p., 31 Mar. 2014. Web. 30 Apr. 2014. <http\%3A\%2F\%2Fwww.savetibet.org $\% 2$ Ftibetan-nun-sets-fire-to-herself-outside-monastery-in-first-self-immolation-in-bathang\%2F)>. 
By reacting to the self-immolations in this fashion, the Chinese government has effected a shift in the overall focus of the ritual. At its inception, auto-cremation was a protracted ritual enacted for viewing by government officials as a protest of a perceived war on religion. Now, it is an active contestation with government officials before, during, and immediately after the ritual. Immolation still follows the ritual pattern set by the Medicine King - anointing with fuel, the making of final vows, and the chanting of slogans or mantras during the immolation. Yet the role of official disproval is no longer perfunctory, but rather quite active. So while immolation has always been an act of religious defiance against 'anti-Buddhist measures' of the state ${ }^{99}$, the ritual now resembles actual secular warfare in an unprecedented fashion. This is a direct result of the changing of the role of the antagonist in the ritual.

As has been demonstrated, the role of the Chinese government has been not only as the perceived inciter of acts of immolation, but also as an active shaper of the ritual itself. This interaction has changed the method of the ritualized protest. Further, once 'acting as a lamp' meant shining a light on your grievances with the government. Now, it means attempting to shed light on the Tibetan situation - for viewing by the Han population and international community. The resultant relic of the ritual - a photo or video- is functioning to apply pressure and have agency in a way that Tibetans cannot. This is accomplished by simply being seen by the both the Han Chinese and world at large. And it is in this fashion that the relics have come to function as the 'weapon' of this ritual. By shutting down wifi and electricity, the PRC is actively engaging in the warlike aspects of this ritual - attempting to disassemble the weapon, if you will. Yet what matters about their action is that is a reaction - and further repression. And both of those only serve to incite further acts of ritualized auto-cremation.

Yet, the Chinese government is by necessity not the only authority involved in this conflict. If immolators suppose themselves to be acting in defense of the Fourteenth Dalai Lama and the Tibetan right to sovereignty, then certainly stance of both the Dalai Lama and the CTA on the matter should have some import.

\section{The Role of Tibetan Authority in Tibetan Auto-Cremation}

Immolators, both in Tibet and in exile, frequently call for the return of the Fourteenth Dalai Lama to Tibet whilst in the act of auto-cremation. And as all exiled immolators presumably accept Sikyong Lobsang Sangay as their Prime Minister and secular leader in exile, he is also necessarily involved in the ongoing interaction between exiled immolators and the PRC. Certainly at least in the regard that, as the Dalai Lama has stepped down as secular leader - it is Sangay who is responsible for representing Tibet in official government talks with China. However, what is most important to note about the role of both the Dalai Lama and the Sikyong, is that they are not authorities in the sense that they are directing or interacting with the immolations. But rather, they are the authorities which immolators believe themselves to be protecting. The reasons for his actions remain unclear, but, the Dalai Lama seems to

\footnotetext{
99 Han, Christina. "Cremation and Body Burning in Five Dynasties China." p.13 Journal of Chinese Studies 55 (2012): n. pag. Web. 29 Apr. 2014. <http://www.cuhk.edu.hk/ics/journal/articles/v55p001.pdf>.
} 
be presenting himself as unable to do anything more than advise his followers. Rather, he does seem to agree that the immolators are protecting him. This has been reflected in the response of both Dalai Lama himself and the CTA to the immolations.

The Sikyong was democratically elected by Tibetans exile and installed in office in 2011. With the exception of one, all Tibetan auto-cremations have taken place since the time that the Sikyong took office.100 As we have seen, political acts of selfimmolation necessarily take place during times of political upheaval. The Sikyong taking secular power requires that the Dalai Lama relinquished it. It was the first time in history that a Dalai Lama willingly gave up secular power over the Tibetan people.101 The installation of the Sikyong constitutes a political change in exile that also fits the political model of the medieval Chinese immolations.

In his role as an exiled authority, the Sikyong issued a 'white paper' aimed at examining "the underlying causes of the increasing number of self-immolations that are currently engulfing Tibet."102 Lobsang Sangay does not mince words about his opinions, opening the paper with an introduction that ends with this sentence: "As we have repeatedly said, the blame for and the solution to the crisis in Tibet lies in the hands of the Chinese leadership." The white paper itself is a clearly delineated explanation of what Sangay refers to as "China's massive policy failure in Tibet over the course of more than 60 years of its rule." The Sikyong does make primary mention that "The Central Tibetan Administration has made many appeals to the Tibetans in Tibet to desist from self-immolation." Despite calling for an end to further immolations, he never says directly that they are morally wrong nor speaks ill of those whom have already committed the act. 103 When giving a talk on "Challenges and Opportunities for Tibetans in Exile" at the National Endowment for Democracy in Washington, D.C. on March 5, 2014, he elucidated his reasoning for such a tactic.

When asked by an Amnesty International representative why the CTA has called for an end to the "non-violent protest" of self-immolation, given that this might create the opportunity for violent protests to arise, the Sikyong was equally as direct in person as he was on paper.

"Now, as far as self-immolation is concerned, yes, we discourage drastic actions by Tibetans inside Tibet. Or even protest. Mainly because, you know the consequences

\footnotetext{
100 Sangay, Lobsang. "Challenges and Opportunities for Tibetan Democracy in Exile." National Endowment for Democracy, Washington, DC. 5 Mar. 2014. Speech.

101 Sangay, Lobsang. "INAUGURAL SPEECH OF KALON TRIPA DR. LOBSANG SANGAY - Central Tibetan Administration." Central Tibetan Administration. N.p., 8 Apr. 2011. Web. 30 Apr. 2014. <http:// tibet.net/2011/08/08/inaugural-speech-of-kalon-tripa-dr-lobsang-sangay/>.
}

102 Sangay, Lobsang. "Why Tibet Is Burning..." Tibetan Policy Insitute, 2013. Web. 30 Apr. 2014. <http:// tibet.net/wp-content/uploads/2013/02/Whitepaper-Final-PDF.pdf>.

103 Sangay, Lobsang. "Why Tibet Is Burning..." Tibetan Policy Insitute, 2013. Web. 30 Apr. 2014. < http:// tibet.net/wp-content/uploads/2013/02/Whitepaper-Final-PDF.pdf>. 
if Tibetans protest inside Tibet. They get arrested. They get tortured. And sometimes they disappear. And many die as well. So, given the fact that you know the consequences, it's easy for us from the outside to discourage that. Hence, as far as self-immolation is concerned, we discourage that because it is harming them. Now, having said that, we support their aspirations though. Because their aspirations are a universal aspiration. As a human being, you don't want to see the protest in the form of self immolation, even though its non-violence in the sense that you are not harming any Chinese person or Chinese property. But then, you are harming yourself. But life is precious. We want to see every Tibetan live and see the day that freedom is restored in Tibet. That's why as far as self immolation is concerned, as a human being we discourage, as a Buddhist we pray, and as a Tibetan we support their aspirations. We magnify why they are suffering, why they are doing it."104

This Sikyong's message seems to echo the doctrinal confusion regarding whether or not certain types of suicide are actually non-violent, as well as the tension between the preciousness of human life and the necessity of defending not only the Dharma but Tibet's right to sovereignty. More importantly, though, his refusal to castigate the auto-cremators places him in direct opposition with the Chinese government with which he has been chosen to negotiate. So while the immolators themselves may not be listening to the CTA as an authority on their activities, certainly the words of the Sikyong are of import to the PRC. This unquestionably holds sway over the behaviors of the Chinese government, and this in turn effects the lives of the autocremators in Tibet. So the influence of Lobsang Sangay cannot be ignored.

There is, however, another voice that the Sikyong seems to be echoing - one that is unquestionably more influential for modern Tibetans than any scripture or historical precedent - that of his predecessor, the Fourteenth Dalai Lama.

Westerners have maintained an undercurrent of distress regarding the Dalai Lama's failure to unequivocally speak out against the immolations. ${ }^{105}$ As the situation stands, he has repeatedly stated that he supports the Vinaya position that all violence is wrong. He has also publicly stated that he believes the immolations have been ineffectual in bringing about change inside of Tibet. ${ }^{106}$ Nevertheless, this has failed to stem the continuation of immolation practices.

\footnotetext{
104 Sangay, Lobsang. "Challenges and Opportunities for Tibetan Democracy in Exile." National Endowment for Democracy, Washington, DC. 5 Mar. 2014. Speech.

105 Quinn, Sally. "The Dalai Lama's Compassion Disconnect - OnFaith." OnFaith. N.p., 11 May 2013. Web. 30 Apr. 2014. <http://www.faithstreet.com/onfaith/2013/05/11/the-dalai-lamas-compassiondisconnect/21073>.
}

Banyan. "Self-Immolation in Tibet: The Burning Issue." The Economist. N.p., 9 Dec. 2012. Web. 30 Apr. 2014. <107 http://www.economist.com/blogs/analects/2012/12/self-immolation-tibet>.

106 Davis, Carlo. "Dalai Lama: Tibetan Self-Immolations Have Little Effect, But Are Understandable." The Huffington Post. TheHuffingtonPost.com, 13 June 2013. Web. 30 Apr. 2014. <http:// www.huffingtonpost.com/2013/06/13/dalai-lama-tibetan-self-immolations n 3432498.html>. 
So, what remains is to examine the tenets of his position on the situation and try to understand how it might actually be influencing the immolators. Since, clearly, it is not stopping them. We might best achieve this by unpacking several of his statements on the subject and trying to understand their message. Perhaps it is best to view two types of statements - those related to doctrine or religious observance, and those related to politics. By examining these two areas it may be possible to obtain the clearest understanding of his views.

In 1990, long before the auto-cremations began, several Rabbis came to speak with the Dalai Lama regarding how best to preserve a culture in exile. What followed is documented in Roger Kamenetz's, The Jew in the Lotus. During the exchange, the Dalai Lama was asked by the Rabbis how he felt about Tibetan Khampas' use of violence to assert the sovereignty of Tibetans - and to protect his person during his escape. He replied in a fashion which presages his modern stance on immolation.

"Yes, from the Buddhist viewpoint, theoretically speaking, violence is considered just a method. So the method is not very important. What is important is motivation. The goal. Violence is like a very strong pill or drug. For a certain illness it's very useful, but there are a lot of side effects. So the worst thing, at the moment you are about to decide, is that its very difficult to know what the result will be. Only when things happen, then afterward, time goes, then you see whether war or violence really produces satisfactory results. Like the Second World War or the Korean War, I think there were some positive results. But the Vietnam War, now the Gulf War, nobody knows what the results will be. So therefore its better to avoid this, I feel."107

The Dalai Lama is saying here that since one cannot know if violence is worth it in the long run, its best not to engage in it. But sometimes he does understand that it is "reality because of your own survival." 108 And in these cases, he does seem to be implying that one can still have positive motivations which alleviate some of the karmic consequences of violent acts. So if one goes into a sinful act with the right motivations, it can actually function as a beneficial act. However, since one can't know what the outcome will be, it's best to avoid taking the risk. Regarding those that decided to undergo the act despite not knowing what would result, the Dalai Lama has echoed this concept many times. Perhaps the clearest statement elucidating the Dalai Lama's doctrinal understanding of the immolations is what Kovan refers to as a 'GelugOrthodox' response:

Actually, suicide is basically (a) type of violence but then question of good or bad actually depends on the motivation and goal. I think (as) goal is concern, these (self-immolators) people (are) not drunk, (do) not (have) family problem, this

\footnotetext{
107 Kamenetz, Rodger. The Jew in the Lotus: A Poet's Rediscovery of Jewish Identity in Buddhist India. p. 103-4. San Francisco, CA: HarperSanFrancisco, 1994. Print.

108 Kamenetz, Rodger. The Jew in the Lotus: A Poet's Rediscovery of Jewish Identity in Buddhist India. p. 103. San Francisco, CA: HarperSanFrancisco, 1994. Print.
} 
(self-immolation) is for Buddha dharma, for Tibetan National interest but then I think the ultimate factor is their individual motivation ... If motivation (consists) too much anger, hatred, then it is negative (but) if the motivation (is) more compassionate, calm mind then such acts also can be positive. That is strictly speaking from Buddhist view . . . Any action whether violence or non violence, is ultimately depend on motivation."109

Clearly, the implication here is that what determines the morality of the act of immolation is the intention going into it. As Kovan stated, this is reflective of the standard lack of hard doctrinal lines regarding the practice. Insofar as direct reference to Buddhist scriptural interpretation goes, these statements represent the clearest outline of the Dalai Lama's opinion. However, in his autobiography Freedom in Exile the Dalai Lama spoke again about the Khampa guerrillas who protected him during his escape from Tibet. And while this may not be a statement directly about the immolations, it does reveal a more personal take on how the Dalai Lama views those who commit acts of violence in his honor and in support of the Tibetan cause:

"In spite of my beliefs, I very much admired their courage and their determination to carry on the grim battle they had started for our freedom, culture, and religion. I thanked them for their strength and bravery, and also, more personally, for the protection they had given me ... By then I could not in honesty advise them to avoid violence. In order to fight they had sacrificed their homes and all the comforts and benefits of a peaceful life. Now they could see no alternative but to go on fighting, and I had none to offer."110

The final line of this quote is perhaps the most relevant to the message that the Dalai Lama seems to be giving the immolators regarding the precept to avoid violence. It also seems, better than all other extant quotes by him on the matter, to encapsulate the entirety of his involvement in the matter at hand.

Of course, there are those who believe his involvement to be far deeper. The standard Party line from the PRC is that the Dalai Lama is encouraging, and possibly instigating, the immolations both in and out of Tibet. To this his reply is very straight forward, even humorous. He invites Chinese officials to come and search for any possible sign that he may be encouraging these horrifying and morally dubious actions:

"I am very good, please come here and (do) thorough check. Since 2008 crisis, even the former Prime minister Wen Jiabao (who) looks (as a) very nice (and) sensible person, he also accused (me) for the crisis that, it starts from India, I think he also mentioned my name, then immediately I responded, now please some Chinese officials, or international media, please come to Dharamsala (to

\footnotetext{
109 Kovan, Martin. "Thresholds of Transcendence: Buddhist Self- Immolation and Mahāyānist Absolute Altruism." p.782 Journal of Buddhist Ethics 20 (2013): 775-812. JSTOR. Web. 29 Apr. 2014.

110 Gyatso, Tenzin. The Path to Freedom: Freedom in Exile: The Autobiography of the Dalai Lama Ancient Wisdom, Modern World. London: Abacus, 2002. Print.
} 
do) thorough check," the Tibetan spiritual leader said. "Come to here instead of saying from distant. Come here, you will be our guest ... most important guest (and) check everything." 111

Clearly, the Dalai Lama finds any accusation that he might have ever encouraged the spread of this ritual laughable. Indeed, there is no evidence whatsoever to support such a claim. Nonetheless, he is aware that there are those who feel he has not done enough to stop the spread of the immolations. To this, his reply is again clear:

"This is a very, very delicate political issue. Now, the reality is that if I say something positive, then the Chinese immediately blame me. If I say something negative, then the family members of those people feel very sad. They sacrificed their own life. It is not easy. So I do not want to create some kind of impression that this is wrong. So the best thing is to remain neutral."112

So, to unpack these statements is necessary to understand them. As Kovan pointed out, the Dalai Lama is reflecting doctrinal 'equivocating' about suicide. $\mathrm{He}$ makes primary mention that motivation is important in determining the moral correctness of an action. By speaking about the auto-crematory deaths in the terms of 'having no other solution' his act as an authority closely resembles that of the medieval Chinese government. He does seem to be communicating that this is an acceptable last resort method to communicate grievance and express agency. This is particularly true in light of his taking part in the dedicating of memorials for dead immolators. ${ }^{113}$ So it would appear that his denials of the righteousness of auto-cremation are perfunctory. He does focus on the concept that wisdom - meaning forethought and clear understanding of the consequences of one's actions - is an important part of determining the righteousness of an action. Yet, he has never publicly stated that the auto-cremations are unwise. In every way, he does seem to be perfunctorily denying the merit of auto-cremation, while holding up the immolators as protectors of himself and Tibet. This is clearly also the position of the Sikyong. So, in what ways might this be influencing the immolators?

\section{The Self-Manifesting Authority of Tibetan Auto-Cremators}

Given that the immolators believe themselves to be acting in protection of the Dalai Lama and Tibetan government, they are necessarily acting beyond authority of these institutions. This is true if only because acting on his behalf implies that an immolator is doing something the Dalai Lama could not accomplish alone. In this way,

\footnotetext{
111 "Dalai Lama Talks about Self-immolation." Phayul.com. N.p., 26 Mar. 2013. Web. 30 Apr. 2014. <http:// www.phayul.com/news/article.aspx?id=33263>.

112 Tenpel. "Why the Dalai Lama Cannot Condemn Tibetan Self-immolations." Tibetan Buddhism Struggling With DiffiCult Issues. N.p., 10 Mar. 2013. Web. 30 Apr. 2014. <http://buddhism-controversyblog.com/2013/03/10/why-the-dalai-lama-cannot-condemn-tibetan-self-immolations-2/>.
}

113 Thinley, Phurbu. "Dalai Lama Honours Martyrs on Tibet Anniversary." Phayul.com. N.p., 10 Mar. 2010. Web. 30 Apr. 2014. <http://www.phayul.com/news/article.aspx?id=26846>. 
the auto-cremators are actually behaving in a fashion which functions with them as an authority in their own right. With this authority, then, they are capable of superseding the wishes of the Dalai Lama (namely for an end to the immolations themselves) for his own good. This sort of behavior reveals the influence of a unique part of the Tibetan canon - the presence of the Dharmapalas.

The Dharmapalas represent an important element of the Tibetan worldview which is at play in immolation culture. A classic group of Dharmapalas are a set of eight wrathful deities, charged "to protect the Buddhist religion and its institutions against adversaries, as well as to preserve the integrity of it teachings... in accordance with the precepts common to the various sects of Tibetan Buddhism." 114 Their visages are displayed on thangkas, carefully embroidered cloths which display the "interpretable paradigms" of their stories. ${ }^{115}$ Dharmapalas are designed to appear indomitable.

Dharmapalas are all generally depicted in a similar fashion. They are frequently naked with their genitals exposed or exaggerated. They wear skins, or dried animal carcasses. Some featured accouterments include, but are not limited to, skulls of blood being used as a chalice, a bow case made of leopard skin, and a shield made of Rhino leather. Most of them ride a transmogrified version of an animal - such as an elephant, horse, bear or vulture. In some depictions the animals are animated precious metals. Dharmapalas all wear a threatening expression. They are frequently shown standing on the defeated bodies of their foes. ${ }^{116}$

But what matters about the Dharmapalas is not only their intentionally terrifying faces. It is what is behind them. Dharmapalas "do not represent merely the darker, destructive side of nature. Instead, by fusing an outer expression of malevolence with an inner valency of compassion, they enfold chaos into the sacred." 117

The Dharmapalas represent an authority above the law and the will of men to do what must be done to protect the Buddhist religion, or Dharma, regional institutions and communities - including Tibet overall, and specific reincarnational lines such as the Dalai Lamas. They contribute to the Tibetan worldview the concept that protecting the sacred through violent means is not only acceptable, but sometimes necessary and praiseworthy. Indeed it does explain a cultural acceptance that one can break Vinaya rules with the right motivation. Certainly this frame of reference eased the acquisition of foreign Chinese auto-crematory practices based on precisely this concept. It also likely

\footnotetext{
114 De Nebesky- Wojkowitz, Rene. Oracles and Demons of Tibet: The Cult and Iconography of Tibetan Protective Deities. p.3 The Hague, The Netherlands: Mouton \& Co., Publishers, 1956. Print.

115 Linrothe, Rob. Ruthless Compassion: Wrathful Deities in Early Indo-Tibetan Esoteric Buddhist Art. p.5 London, England: Serindia Publications, 1999. Print.

116 De Nebesky- Wojkowitz, Rene. Oracles and Demons of Tibet: The Cult and Iconography of Tibetan Protective Deities. p.7-8. The Hague, The Netherlands: Mouton \& Co., Publishers, 1956. Print.

117 Linrothe, Rob. Ruthless Compassion: Wrathful Deities in Early Indo-Tibetan Esoteric Buddhist Art. p.8. London, England: Serindia Publications, 1999. Print.
} 
contributed to the mindset that going against the Dalai Lama's wishes could be for his own good. The connection between the Dharmapalas and the auto-cremators has certainly not been lost on the Tibetan community. Art depicting the immolators as Dharmapalas and pop culture references to the immolators as holy defenders of the Dharma are not uncommon. ${ }^{118}$ Linrothe stated that "The wrathful deity theme is an extremely sensitive marker of doctrinal change because its significance continues to be reformulated". 119 This is particularly true in light of the fact that Dharmapalas never traditionally did violence on themselves, only others perceived as threats to the Dharma. So, engaging with the Dharmapalas in the fashion that exile Tibetans are is indicative of the fact that concepts surrounding acceptable violence are changing. Similarly, by framing auto-cremators in the figures of the Dharmapalas, Tibetans have an extant cultural means through which to accept the authority of the actions of self-immolators. Via this cultural lens, the immolators are increasingly gaining traction as a genuine and recognized authority in the Tibetan community.

Benn states: "'For self-immolators of later periods in Chinese history and the thinkers who defended them in their writings, the fact that eminent monks of the past had made offerings of their bodies conferred legitimacy on the practice."120 The same is true for modern immolators. The more that immolations occur, the more they are accepted as a legitimate option for others. This is particularly true because the immolations have not been entirely unsuccessful. The most significant political shift which has occurred as a result of the immolations is simply that the conversation about Tibet's sovereignty returned to the pages of international news sources with frequency. This is a small political victory, to be sure. But it does not appear to be one that the immolators, or Tibetans in general, are willing to dismiss. Immolators believe themselves to be acting as 'lamps'121 to show the world their experiences in China. Success, in this case, simply means being seen. This is particularly true, when it is taken into the account the attempts to keep immolators from being seen by global eyes.

This perceived success and volume of auto-cremations is of increasing importance in light of the relationship to the Dharmapalas. As has been demonstrated, aggregate self-immolations were the most historically politically efficacious. This action in tandem helped create an army-like quality to the behavior of immolators. When put into the perspective of Dharma and Dalai Lama protecting deities, the auto-cremators have become a sort of holy army in the eyes of many Tibetan exiles.

\footnotetext{
118 Burnett, Katharine. "Tsherin Sherpa: Tibetan Spirit." N.p., n.d. Web. 30 Apr. 2014. <http:// www.rossirossi.com/2013/01/17/Tsherin Sherpa ecatalogue.pdf>.

119 Linrothe, Rob. Ruthless Compassion: Wrathful Deities in Early Indo-Tibetan Esoteric Buddhist Art. p.6. London, England: Serindia Publications, 1999. Print.

120 Benn, James A. Burning for the Buddha: Self-immolation in Chinese Buddhism. p.19 Honolulu: $U$ of Hawai'i, 2007. Web. 29 Apr. 2014.

121 Tsering, Chung. "Online Articles on Self-immolation by Tibetans in Exile - A Brief Survey." Revue D’Etudes Tibétaines 25 (2012): 99-104. Web. 30 Apr. 2014. <http://himalaya.socanth.cam.ac.uk/ collections/journals/ret/pdf/ret 25 07.pdf>.
} 


\section{Exile Tibetan Pop Culture and the Authority of Auto-Cremators}

Tsherin Sherpa is an exiled Tibetan pop artist. He was born in Nepal, in 1968. His father was a renowned thangka artist. Tsherin's work is intended to express the experiences of the younger audience of exiled Tibetans. Sherpa feels that the younger generations relationship with religion and authority is not the same as their forbears. So rather than thangkas, he seeks to create images which investigate the relationship with religion in exile youth culture. Frequently, he paints images which depict the Dharmapalas. Often in conjunction with images which directly reference the autocremations. ${ }^{122}$ The art of Tsherin Sherpa is unquestionably religious, but it has a style which resembles graffiti art. It appears that Linrothe is correct and the Dharmapalas are evolving. What can we determine about how this pop art style depiction of the Dharmapalas reflects the emotions of the exile community in response to the immolations?

"Sherpa's goal in repeating a spirit image is to force viewers 'to see their own perceptions', which he hopes will create a dialogue that comes closer to his intended view for the piece." 123 In other words, like the immolators, Sherpa hopes that his final product will cause viewers to better comprehend the relationship between themselves and the issues he is attempting to bring to light - namely, the increasing disassociation of Tibetan exile youth from Tibetan religious authority, and the plight of the immolators. ${ }^{124}$

His paintings are also intended to depict the many ways in which the Tibetan community is being effected by the auto-cremations, as understood by Sherpa. He states:

"The figures...stand together in unity since we are currently seeing more cohesion around the world of the Tibetan diaspora. The self-immolations have created a shared awareness throughout the community who are now keeping that focal energy alive."125

So clearly, Tsherin has drawn the relationship between the Dharmapalas and the immolators. And not only that, he is reflecting a communal understanding of the selfimmolators as acting as a single entity.

\footnotetext{
122 Burnett, Katharine. "Tsherin Sherpa: Tibetan Spirit." N.p., n.d. Web. 30 Apr. 2014. <http:// www.rossirossi.com/2013/01/17/Tsherin_Sherpa_ecatalogue.pdf>.

${ }^{123}$ Burnett, Katharine. "Tsherin Sherpa: Tibetan Spirit." N.p., n.d. Web. 30 Apr. 2014. <http:// www.rossirossi.com/2013/01/17/Tsherin_Sherpa_ecatalogue.pdf>.

124 Burnett, Katharine. "Tsherin Sherpa: Tibetan Spirit." N.p., n.d. Web. 30 Apr. 2014. <http:// www.rossirossi.com/2013/01/17/Tsherin Sherpa ecatalogue.pdf>.

125 Burnett, Katharine. "Tsherin Sherpa: Tibetan Spirit." N.p., n.d. Web. 30 Apr. 2014. <http:// www.rossirossi.com/2013/01/17/Tsherin_Sherpa_ecatalogue.pdf>.
} 
He also frequently depicts the Dharmapalas in human situations faced by the immolators. In one of his paintings, a Dharmapala is placed under arrest, an obvious nod to the consequences of immolation. Another holds a Rubix Cube, populated with imagery depicting various aspects of modern living and warfare - notably: Mao, Ghandi, a Nazi Swastika, and a hooded Abu Graib Detainee are presented in opposition to peace signs, smiley faces, and doves. By the deity's right hand, a gas can. The title of the work is, 'Your Move'. Clearly, the represents the difficulty of sorting out a solution by a deity charged as a protector. Yet here, the deities are brought back down to Earth. They are dealing with the consequences and implications of human actions. ${ }^{126}$

Of increased importance though, are Sherpa's works which directly address immolation. The most famous of which is appropriately titled, " 49 Gas Cans." The exhibit features $7 \times 7$ rows of gas cans, presented as modern prayer flags.

"Each can is in a different colour, and each bears the face of a wrathful protector spirit. The spirits' faces are painted in ghostly white outline, enmeshed in the starshaped thik tse grid measurement. This grid is an element taken from the traditional Tibetan painting technique for establishing the correct scale and form of icons...

As the colours are not strictly traditional, however, they represent an adjustment to the iconography. Whereas traditional prayer flags are always in yellow, blue, red, green and white colours, here, the purple, orange and pink are new additions to the form. That the white flag is not present is not a comment on what white can symbolise, but rather a comment on shifting Tibetan needs... and as such represents the concept of a new and modern prayer flag responding to new and modern prayers." 127

Clearly, the connection between the Dharmapalas vicious' defending of the Dharma, and the self-immolations has not been lost on either Sherpa or his community. The Dharmapalas indeed here are acting as an indicator of what beliefs Tibetans are renegotiating in their community. The Dharmapalas represent the area wherein the religious and secular meet- where the realities of living with other humans challenge our ideals about upright behavior and where sometimes violence is necessary to save oneself or one's community, or one's religion. Clearly, the Dharmapalas are functioning in the community as a common means of comprehending and dealing with the immolation in a fashion that accommodates the violent nature of the religious act of immolation.

Of course visual art is not the only area in which Tibetans are engaging with the immolations. Music and literature too have seen influence by the practice. In exile,

\footnotetext{
126 Burnett, Katharine. "Tsherin Sherpa: Tibetan Spirit." N.p., n.d. Web. 30 Apr. 2014. <http:// www.rossirossi.com/2013/01/17/Tsherin Sherpa ecatalogue.pdf>.

127 Burnett, Katharine. "Tsherin Sherpa: Tibetan Spirit." N.p., n.d. Web. 30 Apr. 2014. <http:// www.rossirossi.com/2013/01/17/Tsherin Sherpa ecatalogue.pdf>.
} 
Tibetan rock groups, such as the JJ Exile Brothers Band, and various rappers including Tenkhun and jokester Shapaley repeat verses about the importance of Tibetan group identity and strength in the face of exile. Inside China, Radio Free Asia reports that two Tibetan folks singers (one of whom was a relative of an immolator) released songs which praised the immolators for standing up to Beijing. Officially, they were both jailed for six months. However, both singers currently remain missing. ${ }^{128}$

More recently, Jamphel, a singer from Sichuan provence similarly recorded songs in support of the immolators. Jamphel sings:

"In the graveyard of flesh and bone burnt in the fire, there is the honor of the patriotic martyr. There is the suffering of a separated people. In the Snowland of hope for years and months, in the world of patriots ablaze in masses, there is the life of a humble Tibetan. There is the call of a crowd rising up. Be thankful. Be grateful. The patriotic martyrs of Tibet."

Notably, he mentions Thupten Ngodup and Tashi Gyatso by name. Like other immolators have been known to do, he refers to the immolators as "Pawo Pamo". Male and Female heroes. Jamphel appears to remain free. ${ }^{129}$

Similarly, noted Tibetan activist Tenzin Tsundue has written about the immolations on many occasions in magazines and personal blogs, articles, and poems. In particular, the famed poet makes note of the immolations as a source of sustenance for the resolve of the Tibetan people.

"The Tibetan self-immolators instead of harming the Chinese they offer their body and life almost as an act of offering, but in a clear act of resistance. The impact it leaves in the minds of every living Tibetan is such that the struggle has no apparent immediate resolution, it feeds on their life sacrifice and can help sustain the struggle for at least two generations." 130

Here in the arts - an area which is merely interacting with religion - we can still clearly the see the canonization of immolators by the Tibetan community. They are being lionized and held up as martyrs - despite lack of quantitative political success. As in medieval China, each successive immolation legitimizes - and indeed increases the importance of - the next. It would appear that the one clear way the Tibetan art community is dealing with these images is by assisting them in their aim - delivering

\footnotetext{
128 "Tibetan Singers Who Praised Self-Immolations Jailed." Tibetan Singers Who Praised SelfImmolations Jailed. N.p., 14 June 2013. Web. 30 Apr. 2014. <http://www.rfa.org/english/news/tibet/ praised-06132013144450.html>.

129 Rudolph, Josh. "Music Video Honors Tibetan Self-Immolators - China Digital Times (CDT)." China Digital Times (CDT). N.p., 18 July 2013. Web. 30 Apr. 2014. <https://chinadigitaltimes.net/2013/07/musicvideo-honors-tibetan-self-immolators/>.

130 "Tenzin Tsundue: Tibetan Freedom Fighter." Powderzine. N.p., n.d. Web. 30 Apr. 2014. <http:// www.powderzine.com/node/132>.
} 
their message to a wider audience. Yet the immolators are being canonized in a far more literal fashion as well. One which displays the extent to which they are truly developing their own authority in the Tibetan community. In presenting historical accounts of events, the Tibetans seem to behave in a fashion much like the biographers of Fayu and his compatriots. The accounts are told in an almost mythic fashion and sometimes wax more philosophic even the lyrics of Jamphel.

The Tibetan Women's Association released a short article entitled: "A Study of Tibetan Self-Immolations: February 27, 2009 - March 30, 2012 The History, The Motive, and The Reaction". It is dedicated to "The Martyrs of Tibet." It relies heavily on the words of the Sikyong and Dalai Lama - particularly those which implicate China in the immolations and refuse to castigate the immolators. Though it does provide an excellent list of global reactions to each immolation death (there were only 34 at the time of publication), it also includes verbiage which make it clear that this is a religious tract as much as it is a historical pamphlet. For example, "The brave, unimaginable sacrifices of those who have self- immolated will be forever honored. Tibetans, and humanity, are indebted to those who have given their lives so that the rest of us might see peaceful days ahead."131 Even beyond historical recording, there is other evidence that in the self-immolators have become Dharmapala-like 'Pawo Pamo' in the minds of the Tibetan community.

Statues honoring the martyrs have begun appearing in the exile community. "The Tibetan Youth Congress erected a bust of Ngodrup in Dharamsala, giving it the title Chol sum pawo doring ("The Martyr's Pillar of theThree Provinces [of Tibet]")"132 And on March 10th, 2010,

"the Prime Minister of the Tibetan Government-in-Exile... inaugurated the "Tibetan National Martyrs' Memorial" set up by the Tibetan Parliament-in-Exile in the premises of the Tsuglag-Khang complex... [and]

Penpa Tsering, the speaker of the Tibetan Parliament... unveiled a 2-metre tall and 3.2-metre wide steel glass sculpture themed "Tibetan Road to freedom" created by a renowned US-based Chinese artist Weiming Chan at the Museum of Tibet. According to Chan, a graduate from Beijing's Central Arts and Crafts College, the "Tibetan Road to Freedom" sculpture immortalizes Tibetan people's "undying spirit, their will of freedom and struggle against Chinese Communist tyranny."133

131 "A Study of Tibetan Self-Immolations: February 27, 2009 - March 30, 2012 The History, The Motive, and The Reaction." Tibetan Women's Association, n.d. Web. 29 Apr. 2014. <http://tibetanwomen.org/wpcontent/uploads/2012/04/Self-Immolation-report.pdf>.

132 Shakya, Tsering. "Self-Immolation: The Changing Language of Protest in Tibet." p.21. Revue D'EtudesTibétaines 25 (2012): 19-39. Web. 30 Apr. 2014. <http://www.academia.edu/2441693/SelfImmolation the Changing Language of Protest in Tibet>.

133 Thinley, Phurbu. "Dalai Lama Honours Martyrs on Tibet Anniversary." Phayul.com. N.p., 10 Mar. 2010. Web. 30 Apr. 2014. <http://www.phayul.com/news/article.aspx?id=26846>. 
Even more interesting, the unveiling of these statues was accompanied not only by the Tibetan Prime Minister, but also the Fourteenth Dalai Lama. He stated that he came to 'pay homage'. ${ }^{134}$

Further, in 2013, March 10th - a date which has traditionally served as reminder of a massive Tibetan uprising in Lhasa became something even more. Tibet National Uprising Day will henceforth also be celebrated as Tibetan Martyr's Day. ${ }^{135}$

By interacting with the immolations in this fashion, both the Sikyong and Dalai Lama are contributing to the interpretation of the immolators as acting with an authority higher than their own. Benn cites many cases wherein medieval Chinese immolators were frequently recognized after their deaths as having been secret bodhisattvas. ${ }^{136}$ The memorializing of the immolators is functioning in a similar fashion. By positioning them in the public eye as individuals which must be paid homage to, it is clear that they are being credited with an authority of their own which supersedes that of other forms of Tibetan authority. Taking the perception of sacred space into account, it is also interesting that the Tibetan National Martyr's Memorial is placed central to both the home of the Dalai Lama, and the houses of the CTA government. This juxtaposition presents the auto-cremators in a fashion that suggests they are a third arm of Tibetan Exile authority. This is particularly interesting given that most immolations have happened inside Tibet. This placement also increases the perception of the autocremators as a holy army - their efforts being situated somewhere between that work of a government and that of a religious establishment - functioning in support of exiled officials.

So, by equating the auto-cremators with deities charged with protecting Tibetan officials, the act of immolation has come to bring with it a self-manifesting authority in the eyes of the exile Tibetan community. This authority is one which is only increased by the cultural, religious, and governmental categorization of the dead as 'patriotic martyrs'. In this fashion, the Tibetan self-immolators are unquestionably being widely perceived as taking part in ritualized Buddhist warfare.

\section{Conclusions}

Conflicts of secular and religious authority are necessarily what has always driven the practice of self-immolation. Scriptural analysis of the practice proves contradictory. And the Tibetan authorities which self-immolation seeks to protect are themselves undermined by the need for protection. Insofar as immolation functions as a ritualized act of religious warfare, it is clear that the immolations will continue for as

\footnotetext{
134 Thinley, Phurbu. "Dalai Lama Honours Martyrs on Tibet Anniversary." Phayul.com. N.p., 10 Mar. 2010. Web. 30 Apr. 2014. <http://www.phayul.com/news/article.aspx?id=26846>.

135 "March 10 Tibetan National Uprising Day Now Also Martyr's Day." Phayul. N.p., 10 Mar. 2013. Web. 30 Apr. 2014. <http://www.phayul.com/news/article.aspx?id=33129>.

136 Benn, James A. Burning for the Buddha: Self-immolation in Chinese Buddhism. Honolulu: U of Hawai'i, 2007. Web. 29 Apr. 2014.
} 
long as there is a perceived threat to Buddhism and the Tibetan way of life inside China. With the Chinese government functioning as an increasingly active antagonist interfering in the ritual, it seems that this perception is likely to persist for the foreseeable future. Yet as this clash continues, Tibetans both in and out of Tibet are coming to view the immolations' 'martyrs' as a unified authority. This is interesting in that the authority is functioning away from the presence of those it supposed to protect. So how precisely this authority will be wielded in the future remains to be seen.

In the current climate, the auto-cremations are happening at so rapid a rate that it is impossible to report on them in a definitive fashion. Since the beginning of this writing, one month ago, four self-burnings are known to have occurred - all inside Chinese Tibet. ${ }^{137}$ Given the high rate of auto-crematory action, it is no logical jump to see the immolators as functioning in solidarity. What was once the ritual of an individual has become the effort of a group.

To conclude, acts of Tibetan auto-cremation are absolutely ritualized Buddhist warfare. They are warfare because they function in a deeper fashion than simple protest. They involve a group working together to achieve an agreed upon aim - namely Tibetan autonomy and the return of the Dalai Lama. They involve the willingness to die for a cause as a warrior would die. And given that immolations are traditionally and currently most successful in aggregate, auto-cremators are certainly being perceived as a group - more specifically, as a holy army of patriotic martyrs.

Further, this ritualized warfare is shaped by the authority extant at the time of its inception - with the roles of officials effecting not only the actual steps of the ritual, but also the continuance of it. By attempting to auto-crematory rituals from being seen by the Chinese populace and the international community - the Chinese government is actually encouraging more acts of self-immolation by demonstrating that such acts are capable of getting a reaction. By refusing to castigate the auto-cremators, and even honoring them, the Dalai Lama and CTA are giving an unspoken permission to continue them. So it would seem that in modern times it is once again true that the role of outside authority is 'in collusion' with the act of auto-cremation - granting it more power.

Given that all authoritative figures involved in this cycle of immolations (scriptural, Chinese, and Tibetan) are providing no reason for the cycle to end, there is no reason to believe that without international intervention the Tibetan immolations will simply stop on their own. As it stands, there have been at least 130 auto-crematory rituals since the cycle began. If the past is any indication, the number will only get higher until the extant situation changes.

\footnotetext{
137 Savetibet.org. International Campaign for Tibet, 16 Apr. 2014. Web. 29 Apr. 2014. <http:// www.savetibet.org/resources/fact-sheets/self-immolations-by-tibetans/>.
} 